\title{
Tectonic mode switches and the nature of orogenesis
}

\author{
Gordon Lister* ${ }^{*}$, Marnie Forster \\ Research School of Earth Sciences, The Australian National University, Canberra 0200, Australia
}

\section{A R T I C L E I N F O}

\section{Article history:}

Received 28 May 2008

Accepted 31 October 2008

Available online $\mathrm{xxxx}$

\section{Keywords:}

Orogeny

Metamorphism

UHP

Precambrian

Alpine

Tectonic mode switches

Subduction zone dynamics

\begin{abstract}
A B S T R A C T
The birth and death of many mountain belts occurs in lithosphere that over-rides major subduction zones. Here the tectonic mode (shortening versus extension) can abruptly switch, even during continuous and otherwise smooth convergence. If the hinge line of the foundering slab rapidly retreats (i.e. rolls back), the foundering slab creates a gravitational potential well into which the orogen collapses. This motion, coupled with stress guides, can "pull" the orogen apart. A slowing of roll-back (or of hinge retreat) means that the subduction flexure may subsequently begin to be "pushed back" or be "pushed over" by the advancing orogen. The consequence of such changes in relative motion is that orogenic belts are affected by abrupt tectonic mode switches. The change from "push" to "pull" leads to a sudden change from horizontal extension to horizontal shortening, potentially throughout the entire mass of the orogenic lithosphere that over-rides the subducting slab. The sequencing of these tectonic mode switches affects the thermal evolution of the orogen, and thus fundamentally determines the nature of orogenesis. This insight led to us to our quite different views as to how orogens work. It is evident that orogens affected by abrupt "push-pull" mode switches are characterized by high-pressure metamorphism, whereas orogens affected by abrupt "pull-push" mode switches are characterized by high-temperature metamorphism, magmatism and anatexis.
\end{abstract}

(c) 2008 Elsevier B.V. All rights reserved.

\section{Introduction}

Most orogens form adjacent to major subduction zones, and in some sense they act as plate tectonic "bumper bars". In principle this simple (and widely accepted notion) would seem to imply that stretching or shortening of the entire lithosphere should accompany orogenic episodes. If this occurs, large strains can accumulate within the orogen during individual episodes. Both crust and its underlying mantle lithosphere will be deformed. Motion can be accommodated by a range of geometries ranging from terrane-stacks (Fig. 1a and b) to more homogeneous distributions of strain and displacement (Fig. 1c and d). During a "pull-push" orogenic cycle horizontal lithospheric stretching would be followed by subsequent lithospheric shortening, while during a "push-pull" orogenic cycle, horizontal lithospheric shortening would be followed by subsequent lithospheric stretching.

In this context we can describe what happens during orogenesis in terms of a number of reference velocities. Overall shortening will take place in the over-riding plate above a major subduction zone when the subduction hinge is "pushed back" or "pushed over" by the advancing orogenic front [i.e. with $\mathrm{v}_{4} \leq \mathrm{v}_{3}<\mathrm{v}_{2}$ ] (Fig. $1 \mathrm{a}$ and $\mathrm{c}$ ). In this context $\left[\mathrm{v}_{2}\right]$ is

\footnotetext{
* Corresponding author.

E-mail address: gordon.lister@anu.edu.au (G. Lister).
}

the velocity of an advancing reference craton, and it exceeds $\left[\mathrm{v}_{3}\right]$, or the velocity with which the subduction hinge is retreating. The velocity of the advancing orogenic front $\left[\mathrm{v}_{4}\right]$ may remain the same as the velocity with which the subduction hinge is retreating $\left[\mathrm{v}_{3}\right]$, in which case the dynamics may be described as "push-back" (Fig. 1a). Should the velocity of the advancing orogenic front $\left[\mathrm{v}_{4}\right]$ exceed the velocity with which the subduction hinge is retreating $\left[\mathrm{v}_{3}\right]$, the result could be a "push over" the hinge of the advancing plate (Fig. 1c). The resultant geometry would be described as flat slab subduction, but this would have a quite different geodynamical significance than would a change in the relative buoyancy of the subducting slab itself, e.g. due to the arrival of a relatively buoyant oceanic plateau, or a continental fragment, at the subduction hinge. The effect of an indentor is nevertheless still explained by variation of relative velocities as identified above, but now, for example with $\left[\mathrm{v}_{1} \approx \mathrm{v}_{4} \approx \mathrm{v}_{3}<\mathrm{v}_{2}\right]$. In contrast, lithosphere-scale extension can take place when the subduction hinge "pulls away" (or rolls back) of its own accord [so $v_{3}>V_{2}$ ], where again $\left[v_{2}\right]$ is the velocity of the advancing reference craton and $\left[v_{3}\right]$ is the velocity with which the subduction hinge is retreating (Fig. 1b).

It should be evident, from the above, that the velocity of the subducting slab $\left[\mathrm{v}_{1}\right]$ itself does not directly enter into the equation, although through other geodynamic factors (e.g. stress coupling, flexural rigidity, buoyancy etc) this velocity will influence the motions involved above. The velocities noted above are nevertheless not the "drivers" that cause the great differences in the nature of orogeny that result from imbalances as noted above. Their relative values are important, for they 
(a)

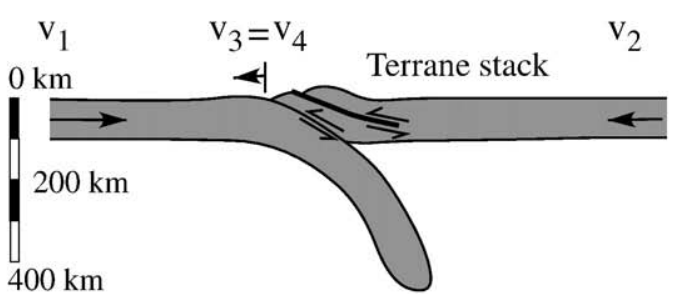

(b)

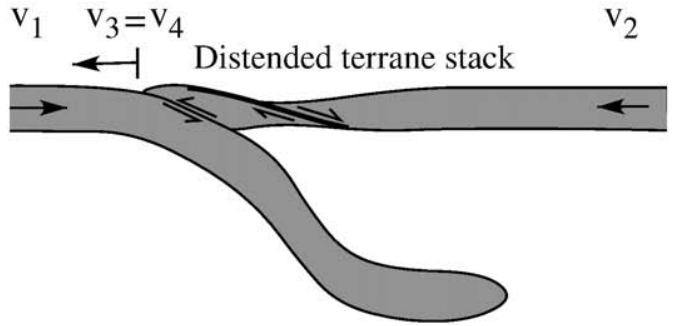

(c) $\mathrm{v}$

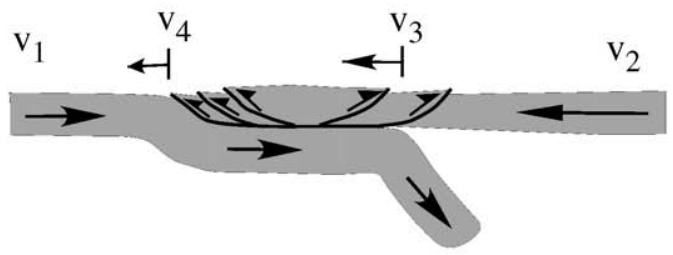

(d)

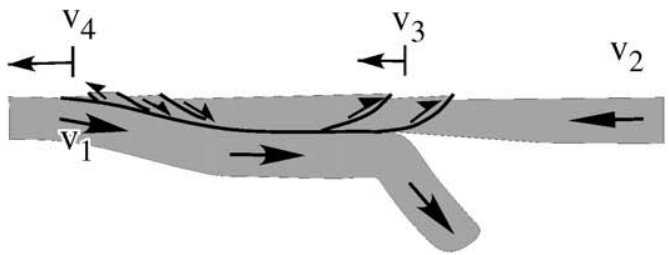

Fig. 1. Velocities that determine tectonic mode switches: $v_{1}$ the velocity of the subducting plate, $v_{2}$ the velocity of the over-riding plate, $v_{3}$ the roll-back velocity of the subduction hinge, and $\mathrm{v}_{4}$ the velocity of the orogenic interface. In: (a) terrane-stacking in the over-riding plate above a major subduction zone takes place because the subduction hinge is "pushed back" $\left[\mathrm{v}_{3}=\mathrm{v}_{4}<\mathrm{v}_{2}\right]$; (b) lithosphere-scale extension and distension of the terrane-stack when the subduction hinge "pulls back" (or rolls back) $\left[\mathrm{v}_{3}=\mathrm{v}_{4}>\mathrm{v}_{2}\right]$ faster than the over-riding plate is able to advance; (c) the orogen has been pushed over the hinge of an adjacent subducting slab, producing a geometry referred to as flat slab subduction $\left[\mathrm{v}_{4}<\mathrm{v}_{3}<\mathrm{v}_{2}\right]$. The orogen is in overall compression; (d) the orogen collapses over the adjacent slab [here with $\mathrm{v}_{4}>\mathrm{v}_{3}<\mathrm{v}_{2}$ ]. In (c) and (d) a large segment of the orogen is in either compression (c) or extension (d) above what must be a weak basal thrust. Note that the velocity of the subducting slab $\left(\mathrm{v}_{1}\right)$ does not directly determine tectonic mode.

offer a frame of reference that allows some comprehension of the underlying geodynamics, in particular in respect to geometry and the 3D-time evolution of the orogen.

\section{Terrane-stacks and tectonic shuffle zones}

Lithosphere-scale dislocations (i.e., brittle and/or ductile faults or shear zones) developed in the over-riding orogen will focus movement and lead to the formation of terrane-stacks (Fig. 1a). The notion of a terrane-stack is central to the interpretations presented in this paper, but the term is used in a deliberately imprecise fashion to allow that a range of different possible interpretations be taken into account. In principle a terrane-stack may be defined as the juxtaposition of different geological terranes as the result of deep-rooted thrusts. These thrusts may slice the geological entity in many different ways hence the imprecision implicit in the terminology. A terrane-stack might be simply accomplished as illustrated in Fig. 1a, with no differentiation of crust and mantle, and several lithospheric slices stacked one upon the other. Alternatively, and the more likely, as is the case with many major thrust systems involving large displacements, the architecture might become considerably more complex. Thrusting can involve initially thin-skinned décollement followed by more deeply rooted thrusts, and thereafter thrusts that bite through and/or transect an already complex geometry. It is immaterial whether these thrusts be considered "in sequence" or "out of sequence". The terranestacks that result will be considerably more complex than the simple sketches provided for illustrative purposes in this paper.

Tectonic mode switches as described above lead to the effects of areally extensive thrusts being superimposed upon the effects of areally extensive extensional detachments, and vice versa. The movement zones that result thus display the effects of large horizontal components of motion in one direction, followed by the effects of large horizontal components of motion in the opposite sense (Fig. 2). We call the structures that result "tectonic shuffle zones" since their thinly-sliced tectonometamorphic stratigraphy, and the juxtaposition of seemingly exotic lenses, reflect the imprint of large, but opposing, sequential motions. Tectonic shuffle zones arise because extensional detachments formed after a thrust event, do not precisely follow the trajectory of the older thrusts, or vice versa. Fig. 2 shows how shuffling caused by reversal of opposing sequential movements on these structures is able to cause thin relict lenses of high-pressure rock to be stranded between adjacent tectonic slices, with each slice reflecting different P-T histories.

Tectonic shuffle zones will develop at terrane boundaries as the result of the opposing movements implied in the models illustrated in Fig. 1. This is of interest because tectonic shuffle zones seem to be aspects common to the structural geology of many orogens, at scales varying from that appropriate to describe a local tectonometamorphic stratigraphy, to scales appropriate to describe the stacking of lithospherescale tectonic slices. Thus we are able to explain the thinly-sliced tectonometamorphic stratigraphy that is a feature common to all known coherent high-pressure and ultra-high-pressure terranes. High-pressure tectonic mélanges may also be associated with such structures (e.g., in tectonic environments as described by Shervais et al., 2004).

\section{Push versus pull in orogenic belts}

It does not seem remarkable to suggest that shortening of the entire lithosphere takes place during orogenesis. It is more controversial to suggest that this can be accomplished by terranestacking, and that in consequence we need to revise our models as to the genesis of high-pressure metamorphic rocks. It is also apparently controversial to suggest that several cycles of lithosphere-scale shortening followed by stretching might take place during the evolution of an orogen. Conventional wisdom reduces orogenesis to merely two stages: a period of construction followed by a period of collapse. This contribution considers these issues and establishes the geometric basis of a different paradigm as to the nature of orogenesis.

In the modern Earth it can be argued that "push-back" against adjacent subduction hinges currently thickens the Andean lithosphere and simultaneously moves the trenches steadily closer to the spreading ridges from which the descending plate originated. In contrast, in Myanmar and southward into the Andaman Sea, in the western part of Indonesia, subduction hinges in the Indian plate are apparently "pulling away" from the adjacent orogen. This movement is taking place in directions roughly orthogonal to the adjacent arcs (irrespective of the direction of relative plate motion), stretching the over-riding crust (and lithosphere) and producing structural trends at various degrees of obliquity to the direction of relative plate motion.

There are thus two types of orogenic systems that can be distinguished on the basis of the behaviour of an adjacent subduction hinge. Compressional orogenesis occurs during periods when the overriding lithosphere pushes against (or over) an adjacent subduction hinge. Periods of extensional tectonism usually have their origin in the 


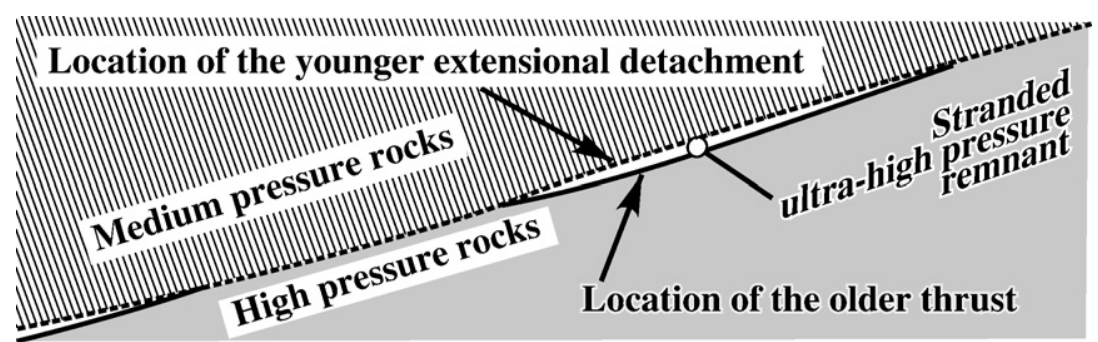

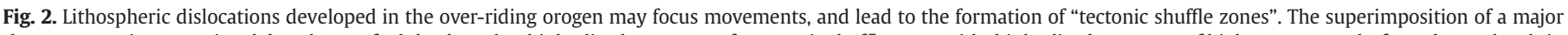

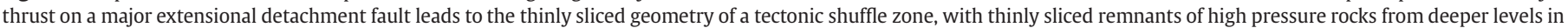

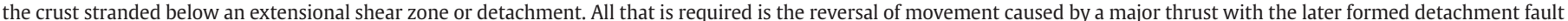
not exactly coinciding with the locus of the earlier formed thrust.

retreat (or "roll-back") of an adjacent subduction hinge at rates faster than the over-riding orogen is able to advance (Royden, 1993; Lonergan and White, 1997; Royden and Husson, 2006). Fig. 1a illustrates a simple terrane-stack that may result from "push-back". Fig. 1b shows how this lithosphere-scale terrane-stack can be distended as a result of later extension. Much follows from this simple diagram, in particular focussing our attention on the tectonic shuffle zones where such sequentially opposing movements must be concentrated.

We should not attach too much importance to the relative motion of the subduction hinge in terms of governing the stresses that operate within the orogen. We need also to consider that the orogen can be pushed (from behind) past the subduction hinge, so that the uppermost parts of the lithosphere slide over adjacent flat or gently dipping parts of the subducting slab. In this case the entire orogenic lithosphere is subject to horizontal shortening (Fig. 1c). Once we accept that such "push over" can take place, leading to what is commonly referred to as "flat slab subduction" (Ramos et al., 2002), we must introduce an additional semi-independent variable, namely the migration velocity of the orogenic interface, $v_{4}$. Since the orogenic interface can move with a velocity $\left[\mathrm{v}_{4}\right]$ that is independent of the migration velocity of the subduction hinge $\left[\mathrm{v}_{3}\right]$, in some cases it is evident that $\mathrm{v}_{4} \neq \mathrm{v}_{3}$. Note also that there are factors that independently govern a change in dip angle of the subducting plate, for example the arrival of a buoyant oceanic plateau (Gutscher et al., 2000). Although in this case the velocity of the orogenic interface $\left[\mathrm{v}_{4}\right]$ might be strongly influenced by the velocity of the subducting plate $\left[\mathrm{v}_{1}\right]$, and change to reflect the impact of this event, the transition to "flat slab subduction" is nevertheless governed by the same geometric principles as described above.

\section{Gravitational collapse}

In addition to "pull-back" and "push-back" of the orogen relative to the hinge of an adjacent subduction zone, the list of factors that affect tectonic mode during orogenesis must also include collapse (Dewey, 1988). Once we accept that an orogen can collapse (driven by its gravitational potential energy) we must accept that the orogen can surge (manifested by foreland-directed thrusting) over the foreland itself (Fig. 1d). This means that tectonic mode is also determined by variation in the rate of collapse of overthickened crust within the orogen itself (cf England and Molnar, 2005). There must always be a basal thrust, but the width of the zone affected by shortening depends on how the collapsing orogen interfaces with the advancing underthrust plate (in the case of oceanic lithosphere, e.g. in the Aleutian Arc) or with the advancing craton (in the case where the interaction takes place with continental lithosphere, e.g. in the Himalaya).

It is necessary to consider these additional factors if we want to provide a complete kinematic description of flat slab subduction, for example as described by Coney and Reynolds (1977), Jordan et al., 1983, Ramos et al., 2002, or to consider the geometry of the giant Sumatran megathrust which separates the westward flowing Indonesian crust from the gently dipping subducting Indian and Australian plates (e.g. Whittaker et al., 2007). The velocity of hinge advance or hinge roll-back needs to be considered separately from the velocity of the advancing or retreating orogenic interface. A slab cannot abruptly change its dip, but nevertheless the hinge can rapidly roll-back (cf Coney and Reynolds, 1977; Eaton, 1984). The orogen may collapse at the same time as hinge retreat takes place, and the orogenic interface can then advance over the retreating hinge onto the otherwise flat or gently-dipping part of the slab (e.g. as is the case in the Aegean, or in the Sumatran forearc). The opposite circumstances can also reassert themselves and renewed overall crustal shortening can once again lead to thickening crust being forcibly thrust on the flat slab (Fig. 1c), inverting earlier formed extensional structures. These are again circumstances in which the orogenic interface can move with a velocity $\left[\mathrm{v}_{4}\right]$ that is independent of the migration velocity of the subduction hinge $\left[\mathrm{v}_{3}\right]$, so again in some cases it is evident that $\mathrm{v}_{4} \neq \mathrm{v}_{3}$.

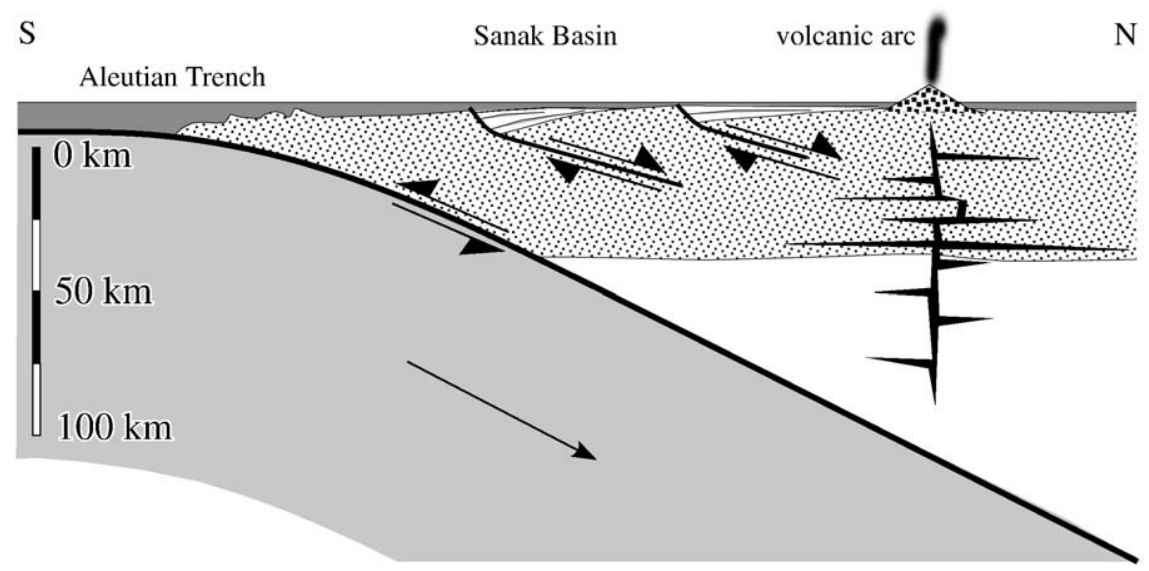

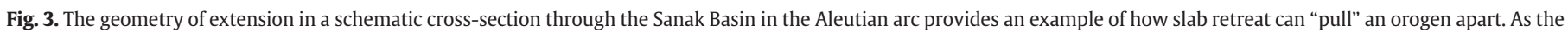

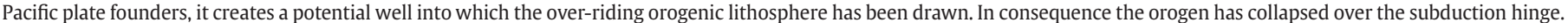




\section{Do orogens collapse or are they pulled apart?}

In passing we should note that slab retreat leads to "pull back" because flow of the orogenic lithosphere takes place to avoid the formation of a gravitational potential well. This flow is transformed into 'extensional' stresses by virtue of stress transfer into the stress guides in the adjacent over-riding plate. These stress guides are defined by the strong zones defined by the brittle-ductile transitions that are always to be found within the continental crust and mantle. These stress guides may be fractured and they then can fail, focussing motion on pre-existing structures that can be quite distal to the rolling back subduction zone that provides the driving force for horizontal extension.

In essence this coupling between flow induced by gravitational collapse and the buildup of effective tension in the stress guides present in any lithosphere allows slab retreat to "pull" an orogen apart. The consequent input of heat associated with the advection of hot fluids or magmas during extension further facilitates gravitational collapse of the orogen. The system is capable of exhibiting all of the elements of complexity theory, with non-linear feedbacks that govern non-linear response. Therefore, with respect to the question "Do orogens collapse or are they pulled apart?" the answer is that (mechanically and geodynamically) both options can be exercised, independently or in conjunction. Moreover, some of the contrasting effects of collapse and pull-apart can be distinguished in contemporary settings.

This point can be illustrated by considering a section through the Aleutian Arc (Fig. 3). The collapsing crust has over-ridden the Aleutian hinge. The gradual steepening of the over-ridden 'flat' zone of the foundering slab provides the motivating 'force' driving extension, generating a deepening gravitational potential well. Note that this is a rather different geodynamic scenario in comparison with the
Himalaya, where the topographic high that has been generated in the Tibetan Plateau drives flow of the collapsing Himalayan orogen southward over the advancing Indian craton (Royden and Burchfiel, 1987), eastward over the Sichuan Basin and northward over the Tarim Basin (Fig. 4 below). Nevertheless, in both cases the kinematics of the frontal wedge involves active extensional normal faults over-riding a basal thrust (Burchfiel and Royden, 1985; Burchfiel et al., 1992). Note also the propensity of such regions in generating great earthquakes!

\section{The independent mobility of orogenic interfaces $\left[v_{4}\right]$}

At this point we begin to discuss one particular orogen in some detail, making the transition between a conceptual introduction to a more rigorous analysis of movement in 3D-time, here for the Himalayan ranges. The real complexity evident in the evolution of any orogen begins to emerge once we begin to consider movement in this way.

The key observation that emerges from the preceding discussion is that the orogenic interface, whether it be trench or collapsing mountain front, is able to move with a velocity (and evolve into a geometry) that is to some measure independent of the velocities (and geometries) of the opposing plates. It is this relative mobility that determines tectonic mode. In the case of collapse, where tectonic mode is determined by differences in flow rates, small changes in relative motions may lead to tectonic mode switches. A wide zone of shortening in the marginal zone of a collapsing orogen may be the result of a transiently higher degree of coupling with the over-ridden foreland, slowing the movement of the orogenic interface. Collapse is hindered, so that the orogenic interface advances with the indenting plate and the zone of shortening widens, as is the case when an advancing indentor impacts on an orogen. The reverse occurs

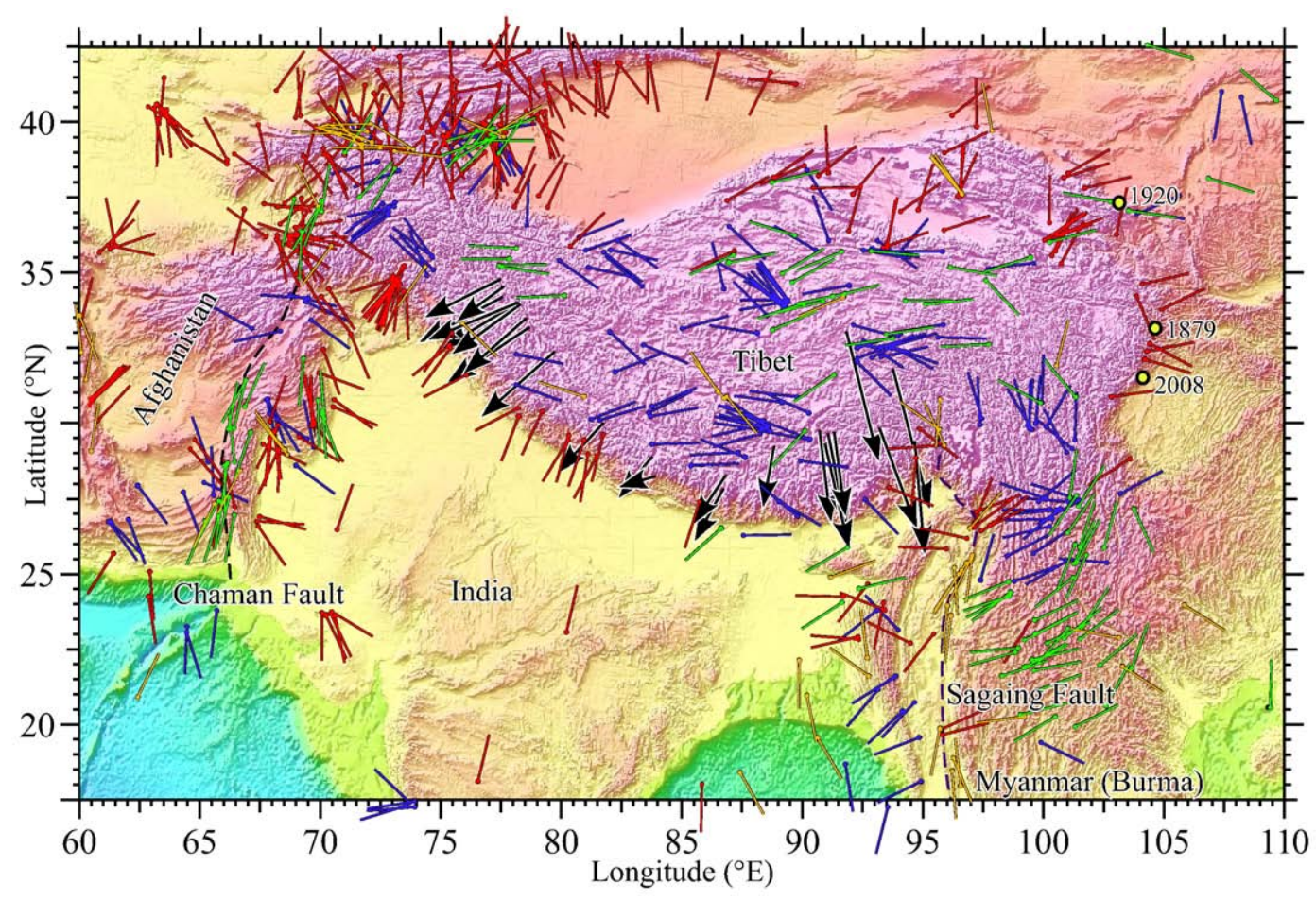

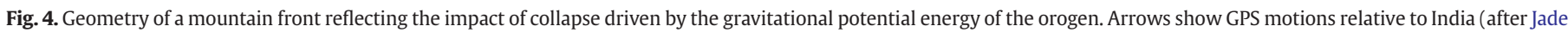

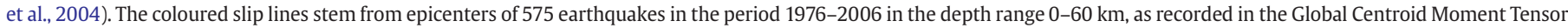

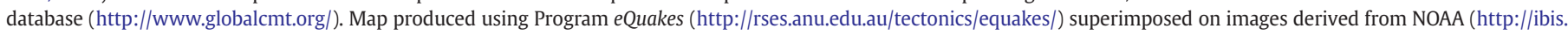

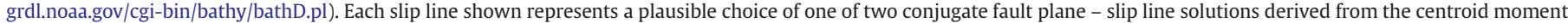

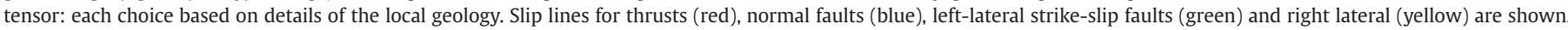

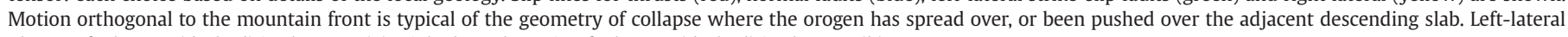
Chaman fault zone (dashed) in the west (a). Right-lateral Sagaing fault zone (dashed) in the east (b). 
if collapse is accelerated (e.g., by yield of the orogenic interface as a new thrust develops, and/or by weakening of warming crust in the hinterland). This leads to a surge that drives the orogenic interface over the indenting plate, developing characteristic arcuate geometries (cf Rosenbaum et al., 2002; Schellart et al., 2002; Schellart and Lister, 2004).

Motion orthogonal to an arcuate mountain front is typical of the geometry of collapse, where the orogen has spread over, or has been pushed over, the adjacent foreland. For example it can reasonably be inferred that the Tibetan crust collapsed southward to create the modern arcuate shape of the southern boundary of the Himalayan mountain chain (Fig. 4). In fact the mountain front defines an almost perfect small circle, with a radius of $1696 \pm 55 \mathrm{~km}$ (Bendick and Bilham, 2001). GPS measurements suggest this flow is still occurring: present day movement is taking place in directions orthogonal to the modern arc (Jade et al., 2004) as illustrated in Fig. 4. England and Molnar (2005) provide a convincing argument that crustal flow in Tibet is driven by the gravitational potential energy of the collapsing orogen: in their words, the orogen behaves more like a 'fluid' than a 'plate'.

This geometry is further illustrated in Fig. 4, using program eQuakes <http://rses.anu.edu.au/tectonics/equakes/> to help analyze the geometry of earthquakes for which motion has been determined with sufficient accuracy to allow calculation of the Centroid Moment Tensor (or CMT). For thirty years this CMT data has been collected by the Global CMT project <http://www.globalcmt.org/> and the results of their calculations made freely available to the scientific community. Program eQuakes uses data downloaded from this site, and overlays the data on NOAA images showing digital elevation, generated by Smith and Sandwell (1997) and Miller et al., <http://ibis.grdl.noaa.gov/ cgi-bin/bathy/bathD.pl>. Data from individual earthquakes or from mapped groups of earthquakes can thereby be analyzed on a stereographic projection, and compared with whatever information is available as to the local geology. For example the program is able to use spherical trigonometry to draw a fault trace as it would appear if projected to the surface, based on the CMT orientation data and depth to the hypocentre. This allows comparison with topographic features, for example as evident on SRTM imagery, and a choice can be made of one of the two conjugate fault plane solutions that can be inferred from the Centroid Moment Tensor (CMT). Similarly the vector defining the slip line on individual fault planes provides additional constraint, for example in the case of kinematically coordinated faults where the fault plane solutions vary widely in their orientation but are nevertheless colinear (e.g., Lister et al., 2008).

In $80-90-\%$ of all cases examined, of the two fault plane solutions available, only one is entirely consistent with the local geology as inferred from this type of information. The result is a set of plausible fault planes, with corresponding slip line solutions. Individually these choices can be debated, and there is a need therefore to establish an internet presence to allow this to take place (e.g. showing a world slip map). The result that will emerge will be structural maps such as illustrated in Fig. 4, which shows colour-coded slip line traces portrayed on a Universal Transverse Mercator projection, itself superimposed on an image derived from <http://ibis.grdl.noaa.gov/cgi-bin/bathy/bathD.pl>. The coloured slip lines stem from epicenters of earthquakes recorded in the Global CMT database <http://www.globalcmt.org/> for the period 1976-2006, in the depth range 0-60 km. Slip lines for thrust faults are shown in red, slip lines for normal faults in blue, slip lines for left-lateral strike-slip faults in green, and slip lines for right lateral strike-slip faults in gold. Forward motion of the Indian indentor is accommodated in the west by the left-lateral Chaman fault zone (Wellman, 1966) on the boundary between Afghanistan and Pakistan, and in the east (in Myanmar or Burma) by the right-lateral Sagaing fault zone (Michel et al., 2000; cf Vigny et al., 2003).

This data can be used to make a number of critical observations. In the NW, this data suggests that the main focus of the India-Asia collision is now in the NW, under the ranges of the Hindu Kush. Furthermore the impact of a currently active indentor can be inferred from the paired clusters of strike-slip faults (with right-lateral faults in the west leading to the Tadjik Basin, and dominantly left-lateral faults in the east, leading to the Tarim Basin). The Chaman Fault can be inferred to continue northward from its presently recognized extent south of the $\sim \mathrm{E}-\mathrm{W}$ Herat Fault, in Iran, and to link into the operation of the indentor. The many active thrusts over the Tarim Basin should also be noted, since these also demonstrate active convergence taking place in this zone.

In the south, this data shows active thrusts rimming the collapsing Tibetan Plateau, but only in the western part of the Himalayan ranges. We suggest that the small-circle geometry of the Himalayan mountain front is diagnostic of the fluid-like behaviour of this collapsing orogen. This geometry reflects the impact of radiating viscous flow, driven by the gravitational potential energy of the collapsing Tibetan Plateau. This inference is consistent with radiating GPS motions relative to India (indicated by the black arrows in Fig. 4, after Jade et al., 2004). The data also shows that thrusts radiate more or less orthogonally from the orogenic welt defined by the Tibetan plateau, southward, northward, and eastward. The effects of this eastward flow of the collapsing Tibetan Plateau is particularly evident in the fold and thrust belt in Sichuan Province, the locus of several catastrophic earthquakes (yellow dots in Fig. 4).

In contrast, in the east, this data shows that the tectonic mode in the Myanmar crust is determined by the competition between two nearly orthogonal movement patterns (Fig. 4). This is a movement pattern driven by the WSW-directed roll-back of the tearing Myanmar slab that lies beneath this zone. Shortening occurs in the foreland fold and thrust belt because this zone accommodates WSW directed motion of crust flowing out from the Myanmar hinterland. This material will eventually be over-ridden by the advancing Himalayan nappes. The Sagaing wrench fault zone marks the locus of accumulating right-lateral offsets, periodically accommodating distortions caused by relative plate motion. At the same time concentric leftlateral strike-slip faults accommodate flow around the eastern syntaxis, causing distortion of the Sagaing Fault and local transtension (Vigny et al., 2003). These concentric left-lateral strike-slip faults are most evident in Fig. 4, for the green lines that show the trend of fault plane slip vectors associated with left-lateral strike-slip earthquakes. From north to south, in a semicircle around the eastern syntaxis, the movement direction associated with these earthquakes changes from towards $\sim 90^{\circ}$ to towards $\sim 250^{\circ}$. This same clockwise concentric pattern of rotation about the eastern syntaxis of the Himalayan ranges is also evident in GPS data (Michel et al., 2000).

\section{The independent mobility of the slab hinge $\left[v_{3}\right]$}

Tectonic mode switches driven by changes in the relative motion of the hinge of an adjacent subducting slab also depend on several competing factors. The hinge of an adjacent subducting slab can be pushed forward (over-riding its own descending slab), for example. This can be the result of a swerve in plate motion, as occurred during the Eocene motion of the Pacific plate. Locally this change in motion resulted in hinge advance, and caused folding and buckling of the descending slab (Schellart et al., 2006). This hinge advance was also responsible for the first period of obduction in New Caledonia. Alternatively the subduction hinge line may "pull back" (or "roll back") of its own accord, so that the hinge line gets closer to the spreading centre from which the slab derived. Roll-back is often the result of a tear that develops in the subducting slab (Royden, 1993; Lonergan and White, 1997; Wortel and Spakman, 2000; cf Mantovani et al., 2001) since this allows the asthenosphere trapped behind the descending curtain defined by the subducting slab to escape laterally. Usually roll-back takes place at a rate that is initially faster than the over-riding lithosphere is able to advance, causing widespread extension. 


\section{Five semi-independent variables}

The above sections demonstrated that four independent factors influence tectonic mode during orogenesis. Even small variations in the rates at which these competing processes take place may lead to tectonic mode switches that have pervasive influence throughout the orogen. Such mode switches can take place abruptly, even during steady and progressive convergence of two opposing plates, and as a result the orogen (on the scale of the lithosphere) may be abruptly switched from overall shortening to overall stretching, or vice versa. Variables that need be taken into account are listed below:

1) the effect of an indentor - the velocity of the orogenic interface $\left[v_{4}\right]$ and that of the subduction hinge $\left[\mathrm{v}_{3}\right]$ can be determined by the velocity of the subducting plate $\left[\mathrm{v}_{1}\right]$ when an indenting craton first begins to impact on an orogenic welt, or when roll-back has brought an oceanic plateau or a continental ribbon to the point that it must be subducted.

2) push-back by the orogen (e.g., against or over an adjacent subduction hinge) - in many cases the orogen is able to "push over" the foreland, or to collapse over and/or around an obstacle, in which case the velocity of the subducting plate $\left[\mathrm{v}_{1}\right]$ may have little influence on tectonic mode within the orogen. Tectonic mode will be determined by the rate at which the orogenic interface is able to advance $\left[\mathrm{v}_{4}\right]$.

3) pull-back (of the subduction hinge faster than the over-riding lithosphere is able to advance) - tectonic mode is determined by the rate of roll-back $\left[v_{3}\right]$. Roll-back is fastest when a subduction zone has been newly initiated (Schellart, 2004b) or when the descending curtain defined by the subducting slab has been recently torn, allowing flow of the asthenosphere through the gap, thence triggering roll-back. If a slab does not tear it will not roll-back.

4) collapse (driven by the gravitational potential energy of the orogen) during which the crust of the orogen flows (or conversely is forced) over the adjacent descending slab - collapse determines the velocity of the orogenic interface $\left[\mathrm{v}_{4}\right]$. Three factors come into consideration namely: i) the rheology of the orogen - if it is weak it will flow; ii) coupling with the advancing foreland - a broad zone of strong coupling will determine a wide zone of shortening in the frontal region of a zone of collapse whereas a weak, newly broken basal megathrust will allow an individual surge of the orogen over the foreland.

5) accommodating (lithosphere-scale) strike-slip or wrench faults since these partition deformation in individual compartments to motions that are more closely orthogonal to the boundaries of the orogenic welt.

Nowhere is the effect of these competing motions more evident than during flat-slab subduction (e.g. Jordan et al., 1983; Kay and Abbruzzi, 1996; Ramos et al., 2002). As indicated above, this geometry may equally result from: i) rapid collapse of the orogen over the adjacent slab; or ii) forcing the crust (and lithosphere) of the adjacent orogen over a descending slab faster than this slab is able to founder. During collapse the crust may extend as it surges over the subducting slab, and the toe of the surge will still be marked by a zone of compressional tectonism. Alternatively, the entire crustal section may be subject to shortening as it is pushed over the adjacent slab (e.g. Ramos et al., 2002; Shervais et al., 2004). Since the motions are relative it matters not whether the underlying cause is increased buoyancy of the subducting slab as opposed to the effect of an increased rate of convergence as the result of more global influences. In both cases the orogen will either be pushed over the flat slab, or it will collapse over it.

These are complicated interactions. It would be fair to ask to what extent might we emerge unscathed from this complexity in terms of our ability to simply describe the tectonic evolution of an orogen. Can we effectively exploit our newly found theoretical understanding? The answer seems to be that as a starting point we need only consider the effects of "push" versus "pull", in particular where such episodes lead to substantial strains that are imposed on the scale of the entire orogenic lithosphere. In these cases tectonic mode switches will fundamentally affect the thermal evolution of the orogen, and precise knowledge as to the thermal evolution of an orogen will reveal the effect of the sequencing of its tectonic mode switches. This is true, however, only if significant strains accumulate before and after the tectonic mode switch takes place, and only if movements before and after the mode switch are sufficiently rapid to allow the thermal structure relict from the prior history to be carried through into the stage that follows.

\section{Push-pull versus pull-push orogenesis}

In regions like the Basin and Range Province of the Western United States it can be argued that the lithosphere of the over-riding plate was first subject to overall horizontal shortening (during the Sevier and Laramide orogenies). Then the lithosphere was thrown into overall horizontal extension by the roll-back or seawards retreat of the flexure of the adjacent Farallon subduction zone (Eaton, 1984). We can look at this sequence of events as an example that shows how an orogen can first be constructed and then collapsed (Coney and Harms, 1984). Or we can regard this as an example of how an orogen may be subject to an overall "push-pull" sequence because of the behaviour of an adjacent subduction zone. According to this latter view, orogens do not have a single constructional phase after which they collapse (cf Dewey, 1988). Orogens can be constructed then torn apart, reconstructed, and then disrupted once again. All orogens are routinely afflicted by such tectonic mode switches, albeit in many cases on time scales much shorter than those we have previously taken into account.

This insight led us to our quite different views as to the nature of orogenesis. In both modern and ancient mountain belts the sequencing of the tectonic mode switches that took place during their evolution define characteristic 'fingerprints'. The fundamental characteristics of an orogen may be shaped by these tectonic mode

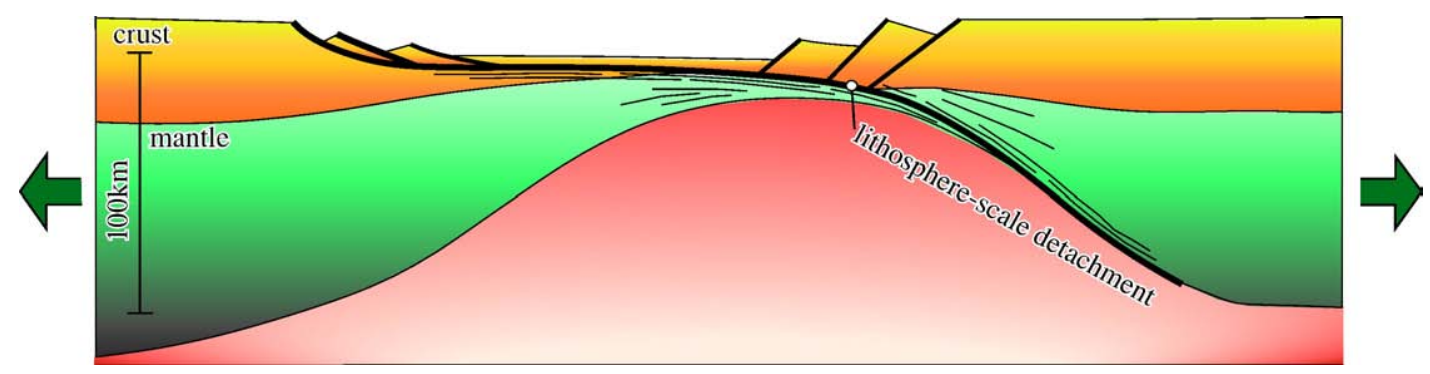

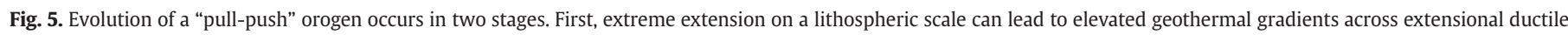
shear zones and detachment faults of very large areal extent (cf Wernicke, 1985). Heat is advected into the system as the result of the rise of magma and hot fluids. 


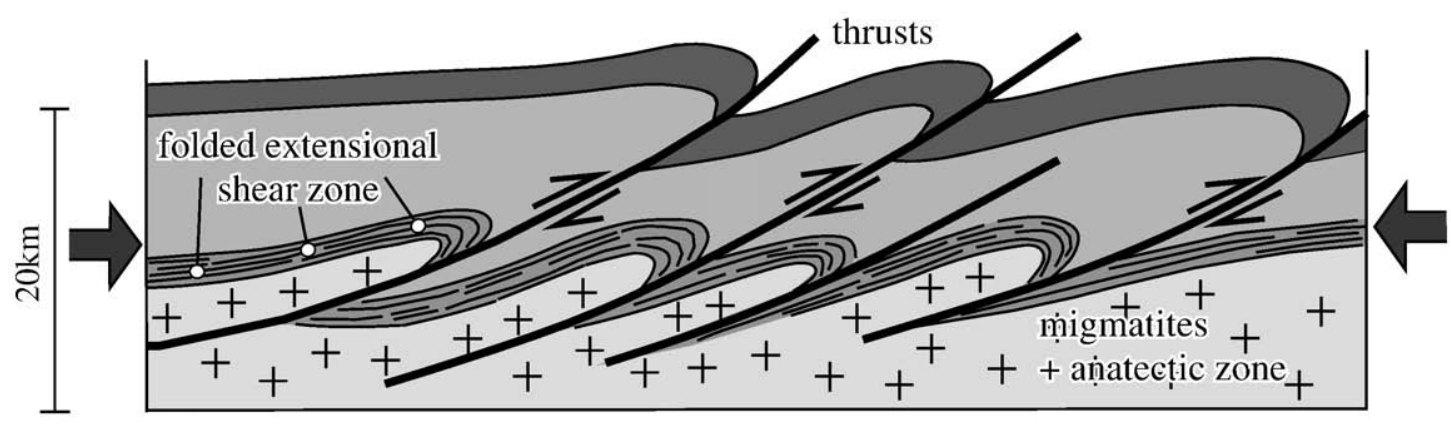

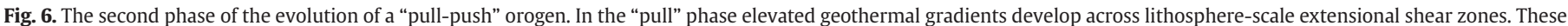

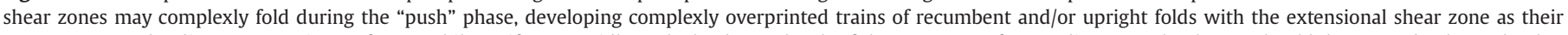

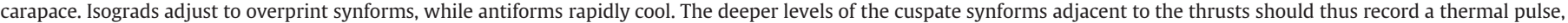
while antiforms 'freeze in' the microstructures related to the previous extensional history.

switches, depending on the magnitude and rate of lithospheric stretching or shortening both before and after individual mode switches, and upon how rapidly motion was taking place, again both before and after the mode switch takes place. The nature and duration of tectonic mode switches fundamentally influences the thermal evolution of an orogen, and these thermal influences directly or indirectly determine the processes that take place within it. For example, as we argue below, it is evident that orogens affected by abrupt "push-pull" mode switches are characterized by high-pressure metamorphism, whereas orogens affected by abrupt "pull-push" mode switches are characterized by high-temperature metamorphism, magmatism and anatexis.

The notion that orogens are first constructed and that thereafter that they collapse was a natural outgrowth of a simple view that can now be refuted. The technology-aided resolution of the nature of active tectonism, and the level of detail of new knowledge as to the evolution of ancient orogens, compel us to move on to a more nuanced understanding of orogenesis. In doing so it will be critical to be far more discriminating in using terms such as "syn-orogenic" and "postorogenic" and better yet to assign those terms to the dustbin. As noted above there can be several episodes during which an orogen is "constructed" just as there can be several episodes during which lithosphere-scale extension tears a newly created orogen apart: with
Alpine orogenesis a case in point. Gravitational energy driven collapse of an orogen can occur in conjunction with slab roll-back, and can also be considered in conjunction with the effect of stress guides that allow an orogen to be pulled apart. Gravitational energy driven collapse of an orogen can occur continually throughout convergence, and is not restricted to an artificially defined so-called post-orogenic phase.

\section{Pull-push cycles in the Precambrian 'metal' orogen}

At the time these ideas began to emerge, we were conducting research in outcrops of the PalaeoProterozoic (1.8-1.5 Ga) orogenic belts, in Broken Hill, NSW, and in the Mount Isa inlier, in NW Queensland, Australia (Betts et al., 2002, 2006; Betts and Giles, 2006). In the context of the ideas being developed in this paper, these could be seen to be "pull-push" orogens, in the beginning subject to $\sim 200$ million years of extension, with some minor inversion events, culminating in a major extension event at $\sim 1.58-1.60 \mathrm{Ga}$, immediately prior to the onset of compressional orogenesis. The simple comparison with the modern Alpine-Himalayan orogen, although often made, could thus be seen to be irrelevant.

We have suggested that such highly extended regions developed extensional shear zones that were potentially regional in extent (Fig. 5, cf Wernicke, 1985). Below the shear zone, where extreme

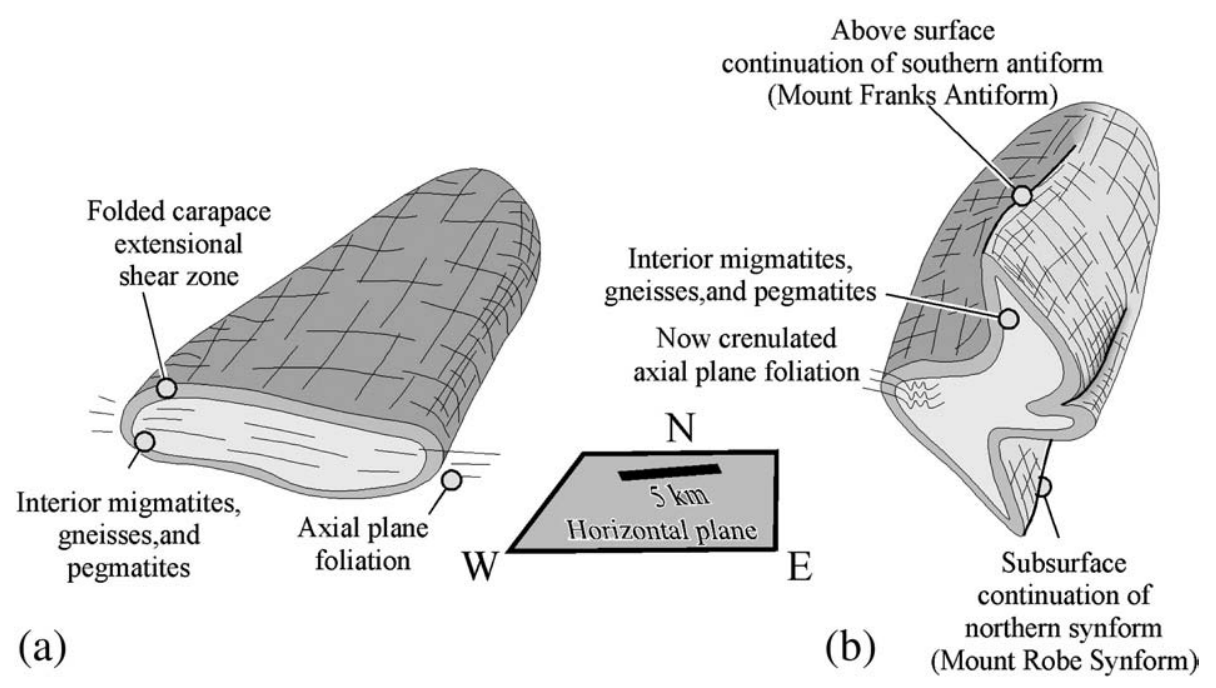

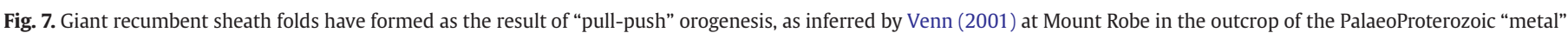

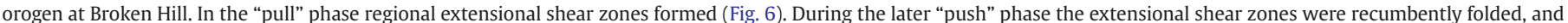

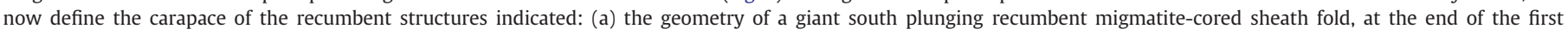

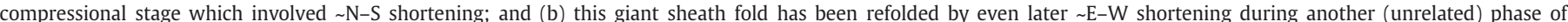

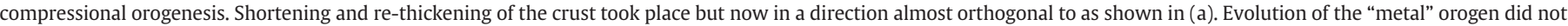

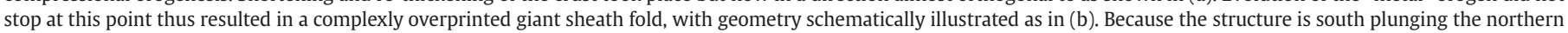
Mount Robe synform marks its lowermost structural levels, and the southern Mount Frank antiform marks its uppermost structural levels. 
stretching has taken place, we expect widespread occurrence of high temperature metamorphism, migmatisation and anatexis. This occurs as a direct result of exhumation and because mafic magmatic activity associated with decompression melting of the underlying asthenosphere advects heat to higher levels of the crust (cf Sandiford, 1989; Collins, 2002). An abrupt mode switch (to a period of compressional orogenesis, or "push") after a period of intense stretching can lead to profound shortening, with the previously formed extensional shear zone becoming recumbently folded (Fig. 6 ), and in more extreme circumstances, with ongoing deformation leading to the formation of km-scale sheath folds (Fig. 7a).

Mega-sheath folds of such extensional shear zones will be cored by migmatites and pegmatites. The carapace of these km-scale structures will be defined by the now refolded extensional shear zone itself. In the case of the 'metal' orogen, as it is exposed at Broken Hill, these sheath folds are typically elongate in a $\sim \mathrm{N}-\mathrm{S}$ direction, with the enveloping surface to the axial plane fabrics of the sheath folds striking in $\sim \mathrm{E}-\mathrm{W}$ directions. Even later $\sim \mathrm{E}-\mathrm{W}$ shortening of these giant sheath folds took place (Venn, 2001), folding these axial plane fabrics into upright folds, and developing $\mathrm{km}$-scale fold interference structures. These structures have complex outcrop patterns, and the 3D form of the now multiply refolded carapace shear zone is only schematically represented (Fig. 7b). Although there is still mapping that must be done before we can capture the detail of such complex 3D structures, there are many potential examples evident throughout in the Palaeoproterozoic "metal orogen" as exposed at Broken Hill, Australia (Nichols, 2001; Venn, 2001), or at Mount Isa. Such structures may typify “pull-push”

(a) W Mount Isa Rift Event
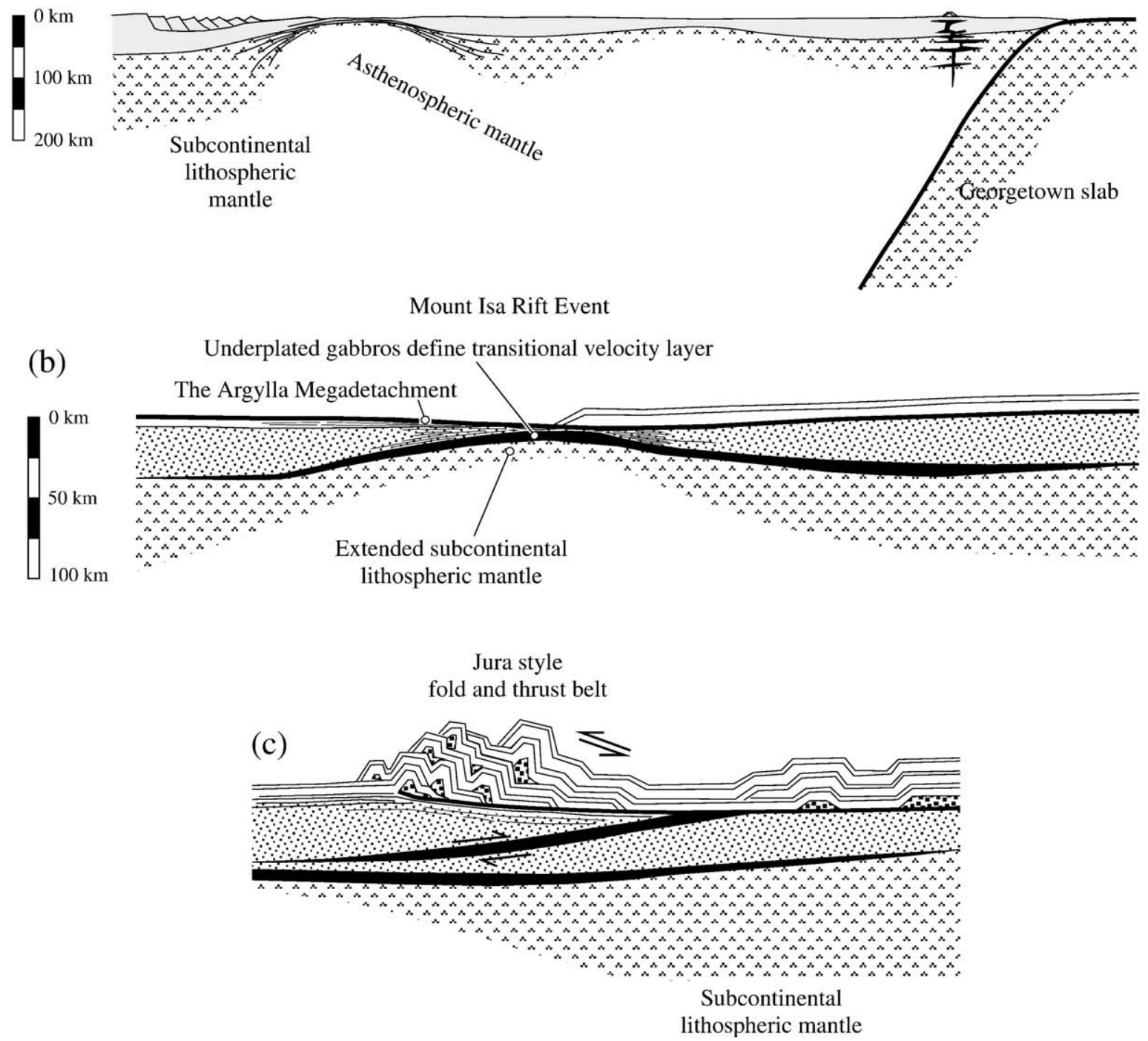

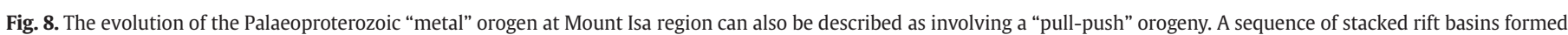

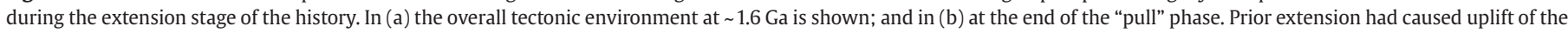

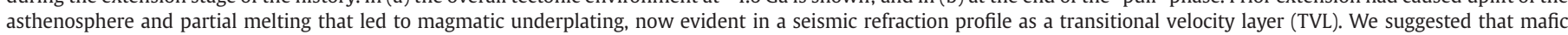

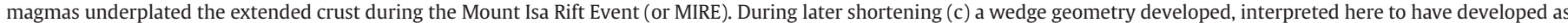

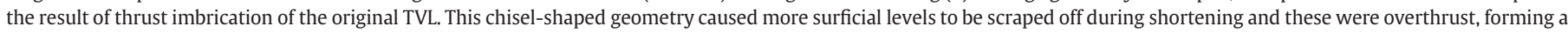

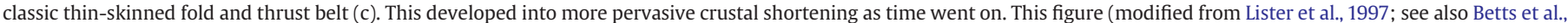

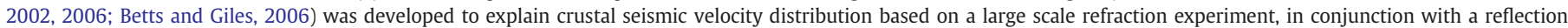

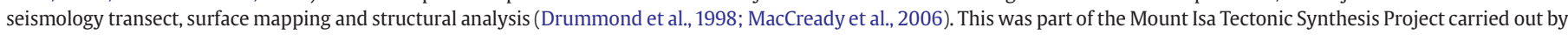
the Australian Geodynamics Cooperative Research Centre. 
orogens, and similar structures may be evident in other "pull-push" orogens, for example in the Appalachian gneiss domes (e.g. Chester Dome, in New England, USA).
Typically the mode switch that takes place at the culmination of a "pull-push" orogeny is marked by a period of static mineral growth during high-temperature metamorphism. The magnitude of the

(a)

Hinge rolls back to continental sliver at $\sim 50 \mathrm{Ma}$

(b)

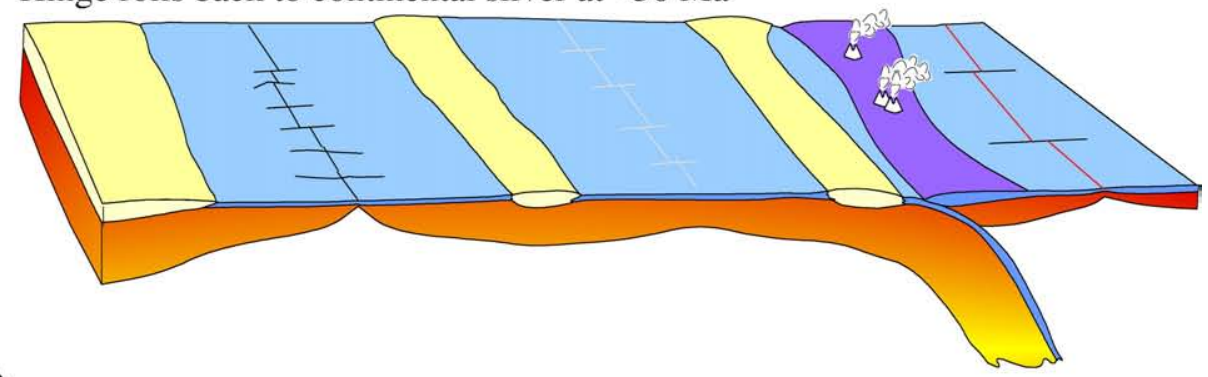

First New Caledonia ophiolite obducted from Pacific slab back-arc

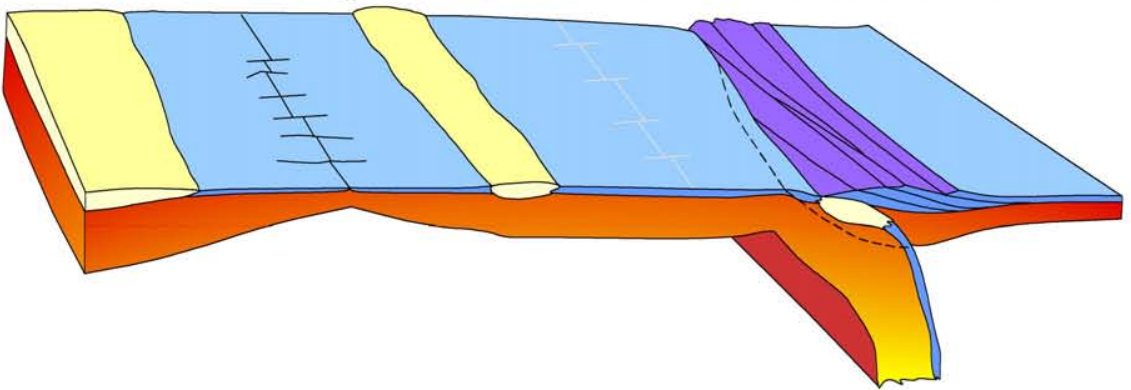

(c)

Giant megathrust accretes sliver and roll-back recommences

(d)

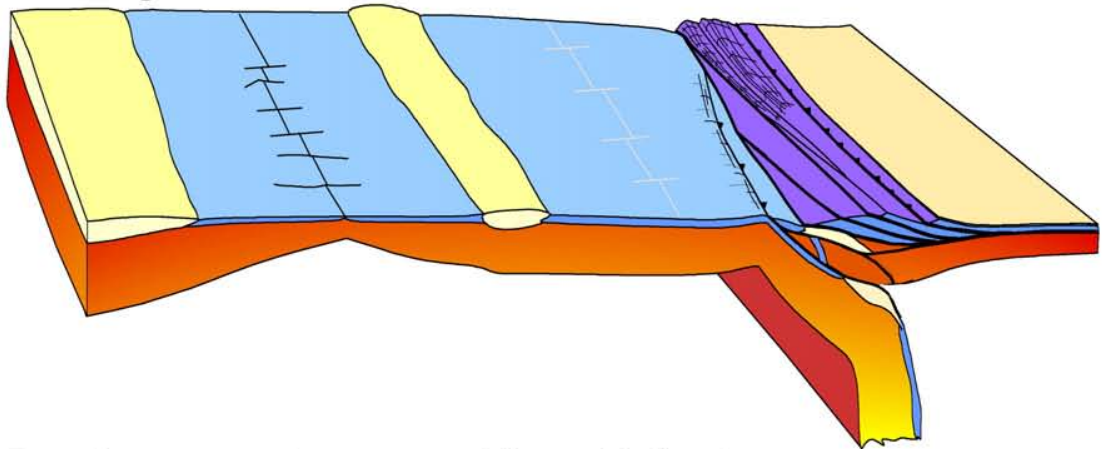

Detachments strand remnants of first ophiolite sheet

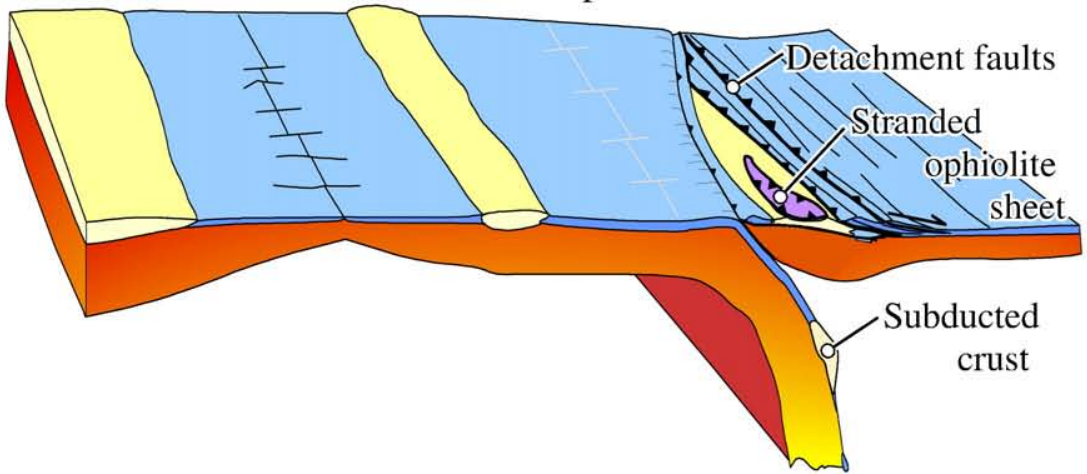

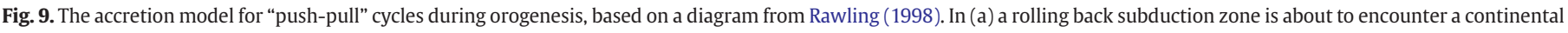

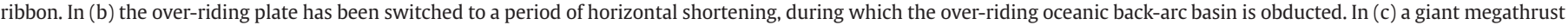

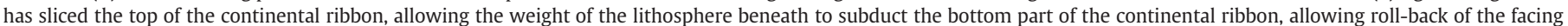

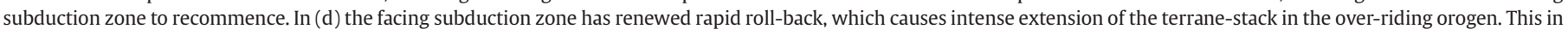

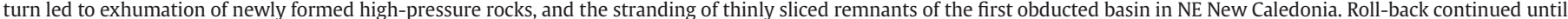

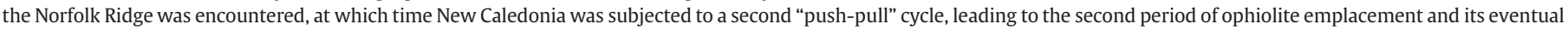

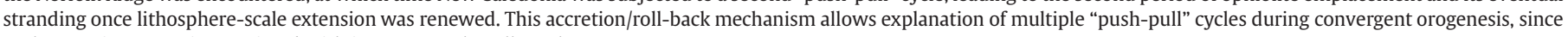
each accretion event is associated with its own "push-pull" cycle. 
associated thermal pulse may be a function of the rate at which the lithosphere was stretching prior to inversion, and the rapidity with which later shortening commences. If sufficiently rapid motions are involved both before and after the tectonic mode switch, the thermal regime established during the preceding extensional epoch will be carried over into the subsequent period of crustal shortening. Ongoing metamorphism may then overprint structures formed during the shortening stage, producing characteristic complexity and confusion as to the earlier link with extension. In the language of tectonic sequence diagrams (Forster and Lister, 2008) "pull-push" inversion cycles are typified by SZ F $\Delta$ cycles, where SZ refers to a ductile shear zone fabric, $F_{R}$ to a subsequent period of recumbent folding, and $\Delta$ refers to a temporally distinct static episode of metamorphic mineral growth that can be inferred from the microstructure. Forster and Lister (2003) show that SZ $F_{R} \Delta$ cycles are characteristic of the extensional metamorphic welt that defines the Otago Schist.
Of course refolded migmatite-cored sheath folds are not the only types of structures that develop during "pull-push" orogenesis. There are a host of other structures that also potentially characterize such orogens. A detailed study of the tectonic evolution of the Mount Isa region led to the conclusion that a later formed thin-skinned fold and thrust belt may have been thrust westward over a mylonitic detachment formed during intense stretching at $\sim 1.6 \mathrm{Ga}$ (Fig. 8a-b). This conclusion was reached after analysis of a seismic reflection study, including in addition a refraction transect and a detailed structural analysis along this $260 \mathrm{~km}$ traverse (MacCready et al., 2006). The mid-crustal Goncharov refractor (Fig. 8c) can be explained by a doubling up by thrust imbrication of a transitional velocity zone formed as the result of the underplating of mafic magmas formed during the prior extensional epochs. The essence of this hypothesis requires re-utilisation of a major extensional detachment during the initiation of later crustal shortening. Tectonic shuffling along this structure will lead to curious juxtapositions
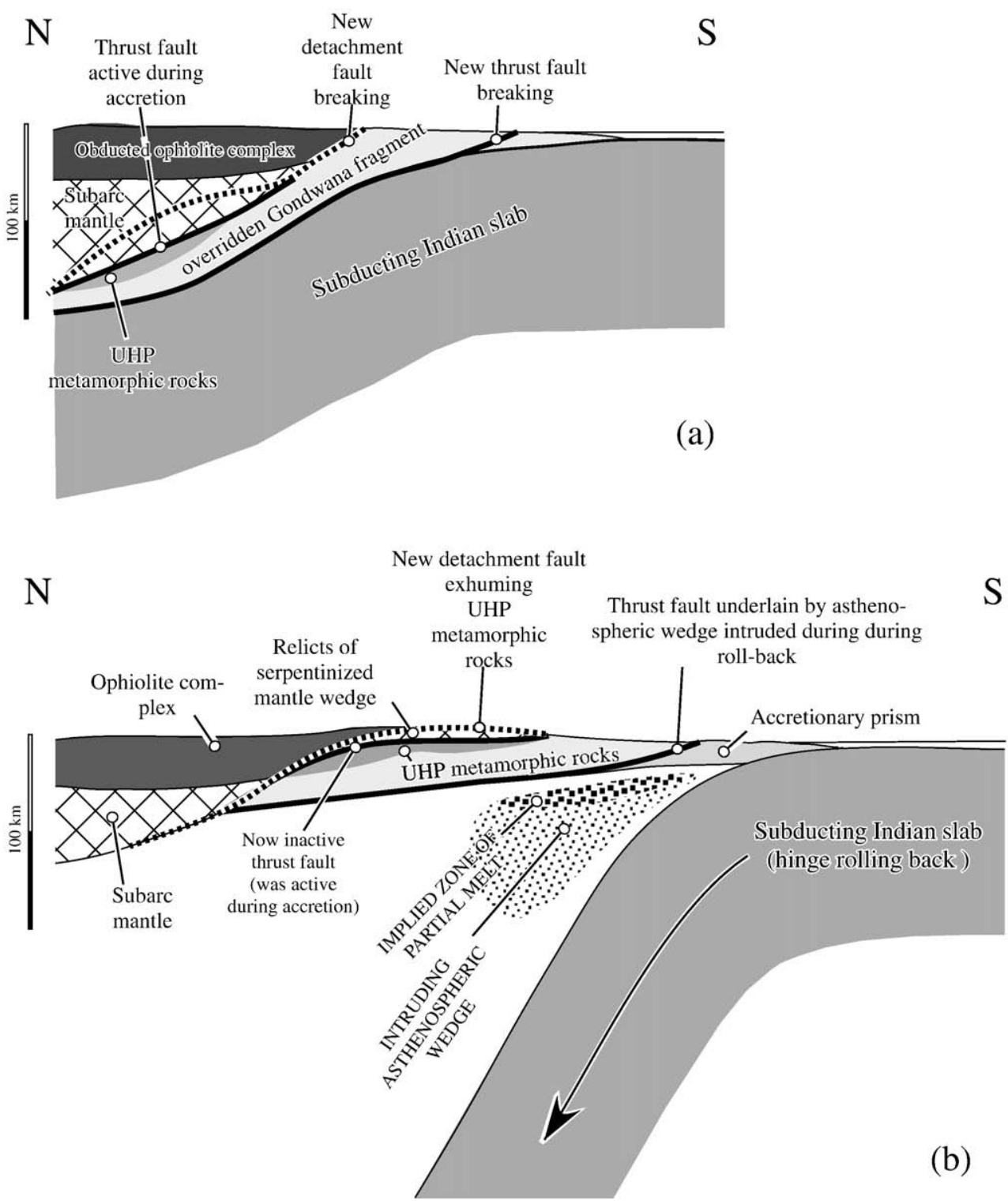

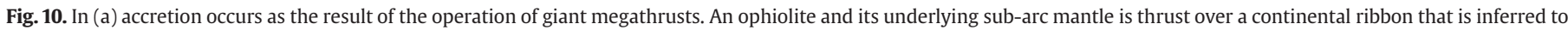

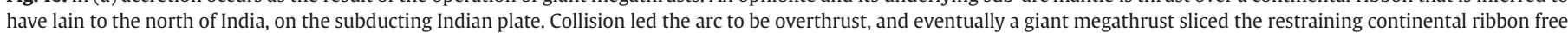

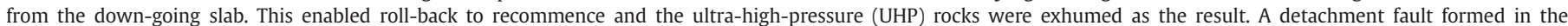

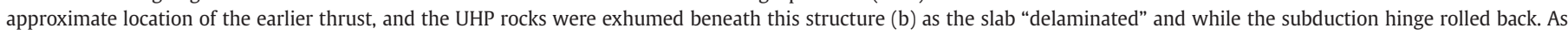

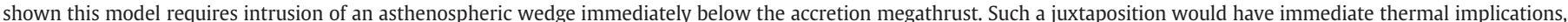

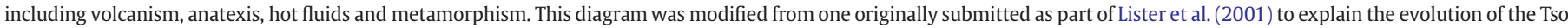

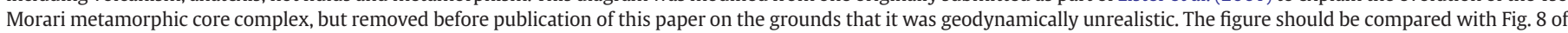
Lister et al., 2001). See text for further discussion. 
of lithologies from a variety of different crustal depths (reflected in variation of peak temperature during metamorphism).

\section{Push-pull cycles in Alpine orogens}

In contrast to orogens typified by "pull-push" cycles, many segments of the modern Alpine-Himalayan orogen appear to involve "push-pull" sequences. A "push-pull" cycle begins with a period of lithospheric shortening, for example typified by the development of a lithosphere-scale terrane-stack, with crustal rocks being thrust deep into the lithosphere along individual major thrusts. It is immaterial whether or not the actual thrust surface is a part of a subduction zone: more often than not we suspect that this is not the case. A major thrust in a terrane-stack is capable of accumulating the relative displacement required, and low geothermal gradients result because of the juxtaposition of individual slices in the terrane-stack. Subsequently, the terrane-stack may be distended as the result of extension driven by roll-back of an adjacent slab. The newly formed high-pressure lithologies are sheared as a result and dragged rapidly back to surficial levels beneath major regional detachments and/or extensional shear zones. This constitutes a simple and effective mechanism to explain the formation, and (shortly thereafter) the exhumation of newly created high-pressure metamorphic rocks.

The "push-pull" scenario outlined above explains many field relationships observed and/or reported from high-pressure terranes: a) the ubiquitous development of thinly-sliced tectonometamorphic stratigraphy; b) the radically different pressure-temperature-time histories that can be inferred for individual tectonic slices; c) the location of high-pressure terranes in locations distal to the subduction zone active at the time of their formation; and d) the close and commonly observed association temporally and spatially between eclogite-blueschist terranes and stranded onshore remnants of ophiolite sheets. The "push-pull" mechanism has advantages in that: a) it does not require abrogation of basic physical concepts in terms of the potential effects of local buoyancy contrast (see below); b) there is no dependence on local buoyancy contrast in terms of either exhuming material from mantle depths, or from at any level within the crust (since the driving force comes from outside of the system); c) it can explain the exhumation of dense rock, such as slivers of peridotite, from deep in the lithosphere (again since the driving force comes from outside of the system); and d) it explains the remarkable tectonic shuffle zones that in some places have been are misidentified as mélanges on major tectonic contacts.

The assertion that local buoyancy contrast plays no role in this mechanism sets us in opposition to all most models that set out to explain how the exhumation of high-pressure rocks is achieved. The mechanism proposed here does not require corner flow (cf Cloos, 1982). Nor does it require a subduction channel (cf Ganne et al., 2006). Nor is channel flow (cf Beaumont et al., 2001, 2004, 2006) in any way involved in the equation. High-pressure rocks do not need to be subducted to great depth and then mysteriously work their way back to surficial levels by burrowing (cf de Sigoyer et al., 2004), or to be uplifted by buoyancy driven diapiric motion or return flow (cf Wijbrans et al., 1990; Chemenda et al., 1995, 2000, 2001; Boutelier et al., 2004; or Warren et al., 2008). Exhumation driven by slab rollback is all that is required. It should be noted that slab roll-back is

(a)

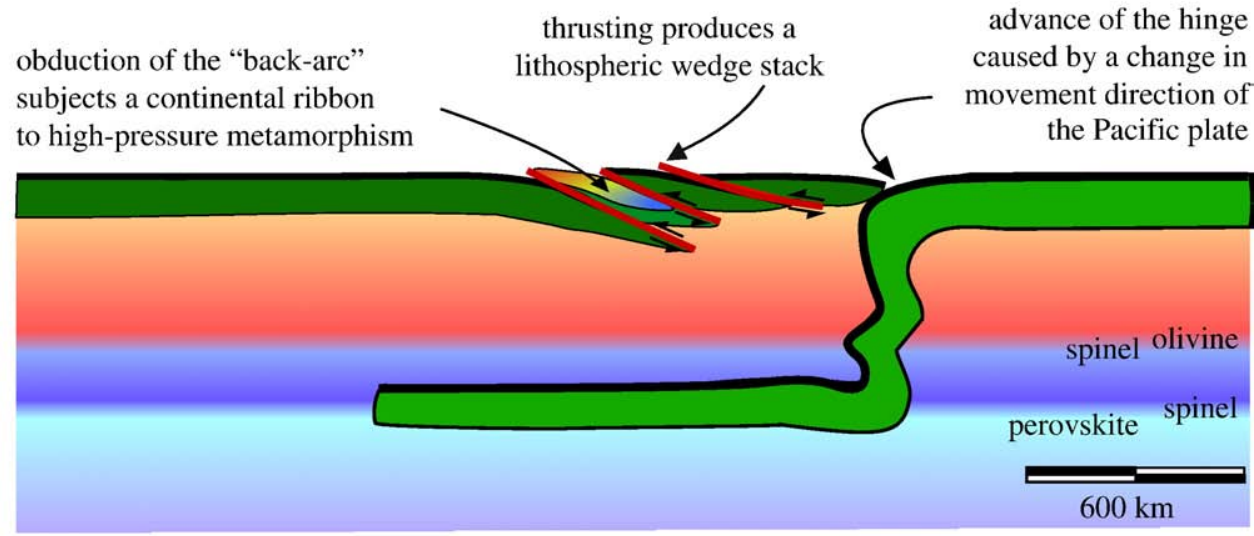

(b)

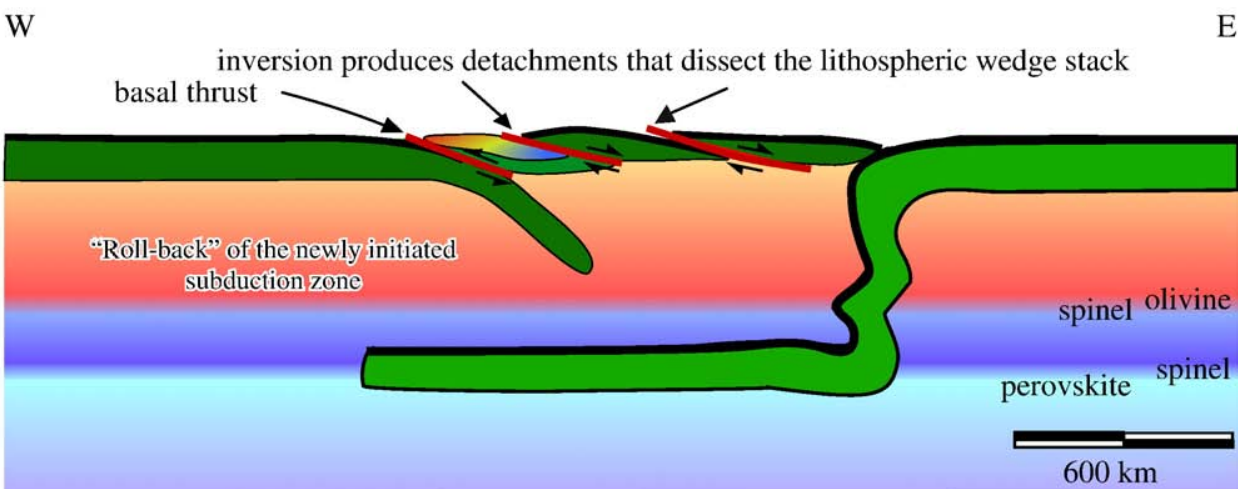

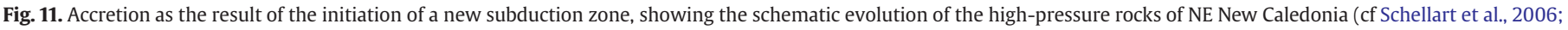

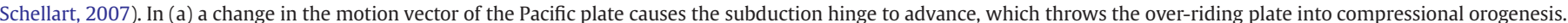

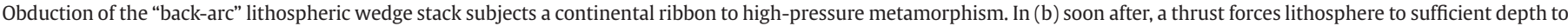

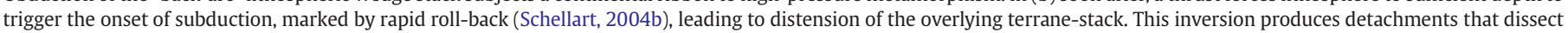

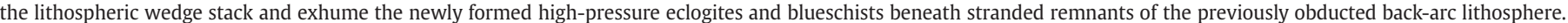


driven by the density differences between the cold subducting lithosphere and the surrounding asthenosphere, so buoyancy contrast does play a role, albeit at a much larger scale.

\section{The accretion/roll-back model for push-pull cycles during orogenesis}

All that the accretion/roll-back model requires for this "push-pull" mechanism to operate is a temporary interruption to the convergence facilitated by subduction. Imagine a subducting slab rolling back towards a sequence of continental ribbons, for example (Fig. 9). Once the slab rolls back to the point that a relatively buoyant continental ribbon, island arc, or oceanic plateau arrives at the subduction zone hinge, the operation of the subduction zone is hindered and it can no longer so readily accommodate convergence. The subduction hinge is thus pinned. Under many circumstances plate boundary stresses will require that convergence should continue, however, so this movement still must be accommodated. Deviatoric stress levels begin to rise, until the system of interacting plates either reorganizes, or the system yields to accommodate these changed boundary conditions. The lithosphere over-riding the subduction zone may be comparatively weak, and it may thus fail, and in consequence, this is where these movements now concentrate. The over-riding plate begins to shorten, and individual terranes stack as they overthrust one upon the other (Lister et al., 2001).

Once this process begins, the crust and lithosphere of back-arc basins will be obducted. The over-ridden footwall may be forced to great depth. Finally, the material hindering subduction will be accreted, either as the result of the operation of a giant megathrust (Figs. 9 and 10), or because a new subduction zone is initiated (Fig. 11). For either circumstance, the act of accretion transfers the blocking material to the over-riding orogen and allows renewed roll-back of the blocked subduction zone to commence. Roll-back in turn triggers lithosphere-scale extension in the over-riding terrane-stack, and rapid exhumation of newly formed high-pressure metamorphic rocks will take place. Thinly sliced remnants of the obducted ophiolite become stranded onshore above detachment faults that slice through earlier formed thrusts and thrust-associated mylonites. And, as shown in Fig. 9, this processes can happen over and over again. Each accretion event is associated with its own "push-pull" cycle, with: i) shortening during compressional orogenesis including obduction of back-arc basin oceanic crust, and folding and thrusting; ii) and thereafter accretion followed by extension and exhumation triggered by renewed slab roll-back.

The accretion/roll-back model for a "push-pull" cycle as outlined above was first proposed by Rawling (1998) and utilized by Rawling and Lister $(1999,2002)$ in considering the tectonic evolution of the eclogite-blueschist belt in New Caledonia in the SW Pacific. It was evident that the mechanism naturally explained the well-recognized association of Tethyan ophiolites with eclogite-blueschist belts. In the specific example of New Caledonia the accretion/roll-back model considered westward roll-back of an east-dipping subduction zone, and the effects that ensue during and after successive encounters of the retreating slab with each of two continental ribbons (Fig. 9). Each encounter leads first to a period of crustal shortening, and terranestacking, and thereafter to accretion. Accretion in turn facilitates renewed roll-back, crustal extension and distension of the terranestack. In consequence, the newly metamorphosed blueschists and eclogites that are formed as the result of obduction are shortly afterwards, rapidly exhumed.

For the past decade, the model proposed by Rawling (1998) has featured in numerous presentations discussing the exhumation of high-pressure rocks driven by slab roll-back. A slightly modified version of a key illustration was recently reproduced (on the front cover of Cloos et al., 2007 and by Baldwin et al., 2007 in the same volume), for example. This model thereby differs little from that proposed by Brun and Faccenna (2008). Rawling's giant megathrust accretion/roll-back model is shown in Fig. 9, with a small but significant modification, namely the implicit (more or less permanent) subduction of crustal material as the result of the operation of a giant megathrust. The megathrusts slice through the obstructing crust on the subducting plate, and thereby allow renewed slab roll-back by 'delamination'.

There is a significant deficiency in this model however: this is not in respect to the mechanism whereby accretion takes place, but in respect to the predicted location of the focus of subsequent extension. As drawn, the kinematic evolution of the geometry explicitly requires the accreted material to be juxtaposed against a wedge of inflowing mantle asthenosphere (Fig. 10). Brun and Faccenna (2008) adopt the same model, and they also note that this juxtaposition has fundamental thermal and mechanical implications since the accreted material is immediately "Heated from below by the asthenosphere that flows into the opening mantle wedge". The problem is that there is little or no evidence for the immediacy of such effects, either in terms of volcanism, anatexis, fluid flow or metamorphism. Therefore we have not pursued this model sensu stricto.

Instead we seek to explain why effects as listed above are found in locations more distal to the active subduction zone. We reconsidered details of the megathrust accretion model in terms of mechanical effects associated with subsequent roll-back model and concluded that thermal and mechanical effects associated with accretion by giant megathrusts ensure that such effects are restricted to the back-arc (cf Brun and Faccenna, 2008). The inflowing asthenospheric mantle wedge (Fig. 10) is not geodynamically realistic, since asthenosphere uplifted to the levels required by this model would partially melt, and the effects of such a magmatic event would be immediately evident. A revised model was published (Lister et al., 2001, Fig. 8) showing rollback of a delaminating slab driving exhumation of high-pressure metamorphic rock in the back arc region, where thermal effects associated with advecting magma and hot fluids can readily explain overprinting Barrovian metamorphism.

In the case at hand the ribbons involved formed much earlier than the period of tectonism in question. They were the result of Mesozoic extension at the eastern margin of Gondwana, as the west-dipping Pacific slab rolled back toward the east (Lister and Etheridge, 1989; cf Schellart et al., 2006). In this model the easternmost ribbon is the Norfolk Rise. The nature of the westernmost ribbon inferred by Rawling and Lister $(1999,2002)$ is disputed (Schellart et al., 2006). Nevertheless it may include fragments of continental origin from the Gympie terrane (cf Aitchison et al., 1998) and may continue south to the Three Kings Rise.

We also note that tomographic data is consistent with alternative and quite different models that explain accretion as the result of the formation of new subduction zones (Fig. 11). Schellart et al. (2006) and Schellart (2007) considered this evolution in the context of a reconstruction of the tectonic evolution of the SW Pacific. They conclude that terrane-stacking was set in motion as the result of a swerve in Pacific plate motion (with effects as shown in Fig. 9). This swerve caused the hinge of the descending Pacific plate to advance, forcing abrupt tectonic mode switches in the over-riding plates. In the case of New Caledonia a switch took place from overall extension and back arc spreading, to overall shortening (Schellart et al., 2006). The first of two major ophiolite obduction events took place at this time (Rawling and Lister, 2002) as the result of westward overthrusting of the former back-arc of the subducting Pacific plate. The high-pressure metamorphic belt of NE New Caledonia was the result (Fig. 10a).

In summary, while we conclude that the act of accretion may indeed involve development of a new megathrust that transfers the restraining buoyant crust to the over-riding terrane-stack as shown in Fig. 9, this is only one way to allow an existing subducting slab to recommence "roll-back". Alternative mechanisms need also be 
considered: for example as shown in Fig. 9. A new subduction zone may develop if one of the underthrust slices penetrates to a sufficient depth to allow a Raleigh-Taylor instability to be triggered (Schellart, 2004b). When this happens the newly formed subduction zone will begin to rapidly founder. Schellart $(2004 a, b)$ shows that relatively rapid slab roll-back may then take place (Fig. 10b), causing rapid extension during this initial period (cf Lister et al., 2001; Schellart, 2004a,b; Schellart et al., 2006; Stegman et al., 2006). In consequence the terrane-stack in the over-riding lithosphere is readily dismembered. Even diamond facies mantle peridotites can be rapidly exhumed as the result of this distension. Local buoyancy contrast plays no role in this mechanism.

\section{Alternative theories for the formation and exhumation of high-pressure rocks}

A subduction zone provides an easy mechanism conceptually to drive rocks down to great depths, and to explain why these rocks eventually suffer high-pressure metamorphism. The difficulty is then to provide a mechanism that can realistically explain their subsequent exhumation. Here we take note that any such mechanism must naturally explain: a) why high-pressure metamorphic rocks outcrop with structural relations as observed, in locations that are far from the active subduction zone; and b) the factors that underlie the prevalent association of blueschist and eclogite belts with ophiolite sheets that formerly over-rode the high-pressure terranes.

The model advocated here meets those criteria. The effects of accretion followed by roll-back allow precise explanations of many aspects of the formation and subsequent exhumation of highpressure metamorphic rocks: a) in respect to the timing of their exhumation shortly after their formation; b) how these rocks can be formed in exactly the same tectonic architecture as that in which they are subsequently exhumed; and c) why the locations in which these rocks typically outcrop are typically distal to the subduction zone that was active at the time of their formation. Not one of the variously postulated alternative mechanisms for the formation and/ or exhumation of high-pressure rocks meet all three of these constraints.

Most models for the formation and subsequent exhumation of high-pressure metamorphic rocks do not take into account the overall context of a particular tectonic environment in attempting such explanations. This leads to many different issues for there is "a devil in the detail". For example in the case of the subduction channel advocated by Ganne et al. (2006): a) there is no direct evidence for subduction in the 'channel' in question; b) tectonic reconstructions are precise enough to allow the assertion that there never was subduction in the direction of motion suggested; and c) the direction of relative movement inferred by these authors can be explained otherwise, since it is entirely consistent with orogen-scale extension inferred on several other grounds. Most models omit essential elements of the tectonic architecture, for example, the association of blueschists and ophiolites, which is often-noted throughout the Tethyan ophiolite belts (e.g. in New Caledonia, Rawling and Lister, 1999). Furthermore most models fail to provide a convincing explanation for the location of ophiolites and eclogite-blueschist belts in positions that are distal to the subduction zone that can be inferred to have been active during their exhumation.

There is thus a great deal of debate as to the origin and subsequent exhumation of high-pressure terranes, and models as advocated in this paper are hotly contested. The counter arguments can be flawed in that they begin with the assumption that the occurrence of high-pressure metamorphic rocks marks the position of ancient subduction zones, but provide no other reason than the assertion that this is where such rocks form. Such reasoning is circular. There is no reason why high-pressure metamorphic rocks should not form in ancient subduction zones, but they can also form on lithosphere-scale thrusts. The requisite pressures can be attained if movements in excess of 100-200 km have taken place on such structures. It may be that this is a merely a question of nomenclature, but subduction zones as typically illustrated involve far greater movements, and penetrate far deeper into the asthenosphere. In fact the pressure-temperature conditions estimated by metamorphic petrologists almost all lie within the $\mathrm{P}-\mathrm{T}$ envelope that we expect within a lithospheric-scale terrane-stack, even for diamond facies conditions.

It is also important to realize that it is not necessary to call on refrigeration adjacent to a subducting lithospheric slab to explain relatively low temperatures at high pressures, in particular if these pressure-temperature conditions are only transiently attained. Cooling can also result because of the juxtaposition of multiple thrust slices, and this will rapidly reduce the effective temperature gradient in any terrane-stack, even one formed in a tectonic environment with an initially high geotherm. Most high-pressure terranes are exhumed within just a few million years of the metamorphism that sets them apart, so there is no chance that thermal relaxation on a time scale an order of magnitude longer than that observed could raise the geothermal gradient sufficiently to obliviate the low-temperature/ high-pressure assemblages.

In respect to the exhumation and exposure of high-pressure rocks, the role of lithosphere-scale extension driven by slab roll-back is currently passed over almost universally in favour of hypotheses related to buoyancy, channel flow, or local extension during convergence (e.g., Chemenda et al., 1995, 2000, 2001). Platt $(1986,1993)$ and Platt and Vissers (1989) provide a clearly written and well-argued expostulation of alternative mechanisms. Platt (1993) describes the limiting constraints. He writes that: "The exhumation of high-pressure metamorphic rocks requires either the removal of the overburden that caused the high pressures, or the transport of the metamorphic rocks through the overburden." Erosion of shortened and thickened crust, may be involved but the mechanisms proposed need also include, either:

1) “corner flow" (Karig, 1980; Cloos, 1982; Ernst, 2001) - leading to the progressive ejection of material from a subduction channel (cf Ganne et al., 2006). We comment that although there is no doubt that such a mechanism could explain occurrences of high pressure rocks as identified in Franciscan mélanges, it is equally possible (considering the works of Jayko et al., 1987, or Shervais et al., 2004) that tectonic shuffle zones have operated in the terranes in question.

2) "buoyancy" (e.g. Wijbrans et al., 1990; Jolivet et al., 1994, 2003) - a mechanism that is often proposed to allow deeply subducted rocks to escape from their surroundings, and to rise back through the mantle to crustal depths. Once the material rises to crustal levels other mechanisms of exhumation are then invoked. However we comment that in terms of what is encountered at outcrop scale, local buoyancy contrast cannot be called upon to drive the motion of relatively small lenticular bodies of rock up gently dipping shear zones in ways as advocated by Ring and Layer (2003) or de Sigoyer et al. (2004). Such buoyancy driven burrowing requires a critical mass, and rheological contrasts far greater than those currently inferred in shear zones. The surrounding rocks would need to be very weak to allow this mechanism to operate. This is true even if the lenses were invariably encased in weak serpentinite, which in any case they are usually not. The shear zones would also need to have been steeply dipping so as to allow the magnitude of the resolved shear stress that can derive from local buoyancy contrast to have been non-negligible. We conclude that local buoyancy contrast is highly unlikely to have driven small and thin lenticular bodies along what appear to have been gently dipping structures. In most cases propositions based on this mechanism smack of "deus ex machina" noting <http://en.wikipedia.org/wiki/Deus_ex_machina> that "The Greek tragedian Euripides is notorious for using this plot device as a means to resolve a hopeless situation." 


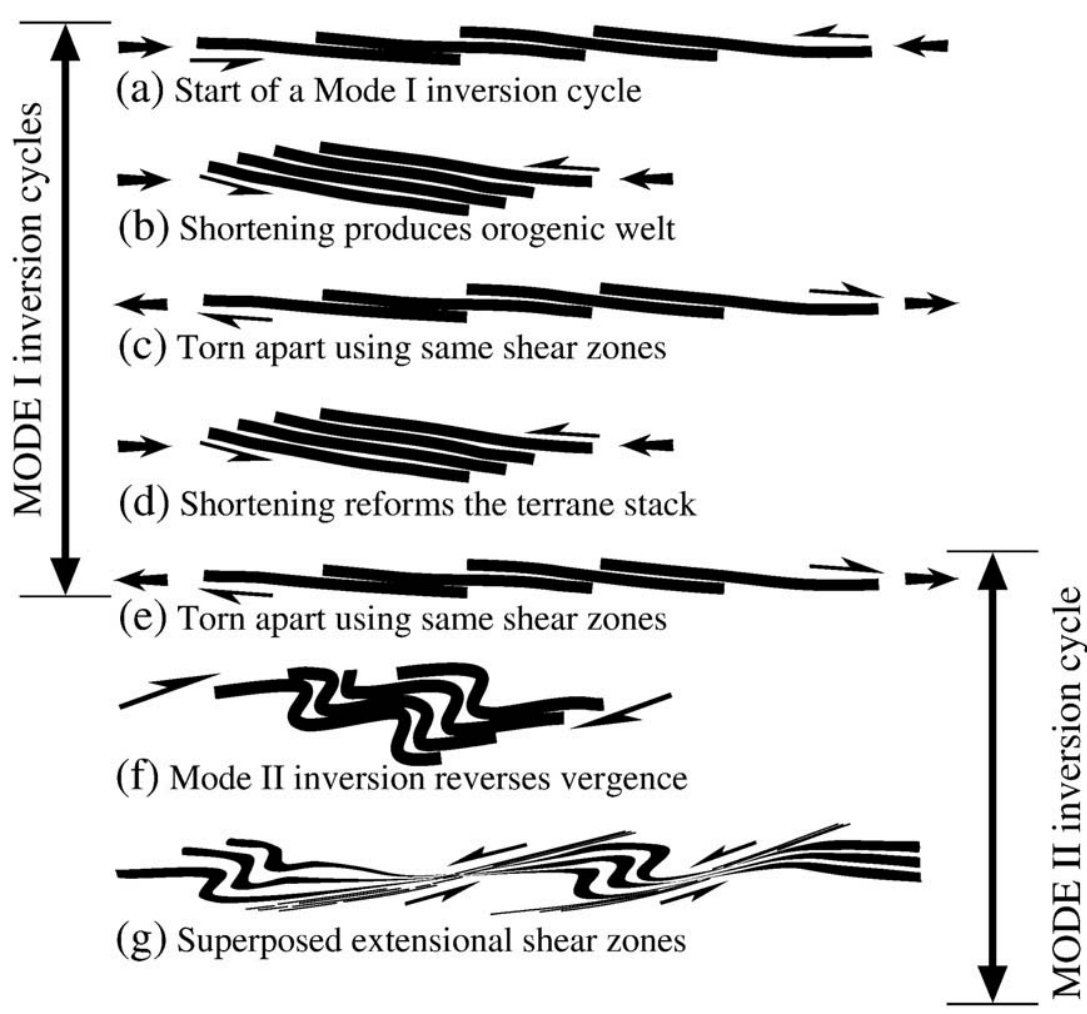

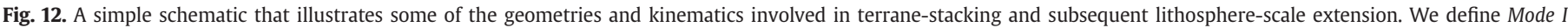

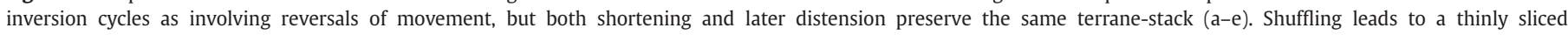

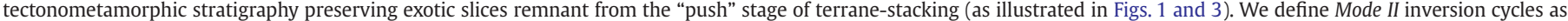

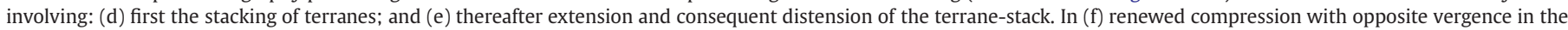

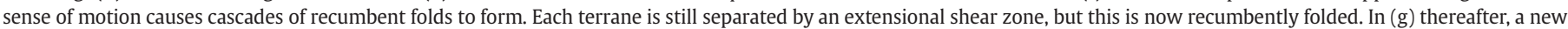

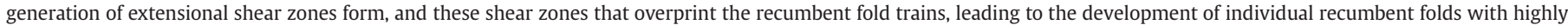

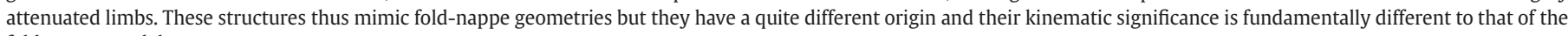
fold-nappe model.

3) "extension" - for example utilizing lithosphere-scale dislocations that drag the high-pressure rocks back towards the surface, as proposed in this paper. Platt (1993) however ignored this mechanism and restricted his focus: i) to extension driven by "the forces associated with contrasts in surface elevation" for example in the upper part of an accretionary wedge thickened by underplating (cf Davis et al., 1983; Platt, 1986); and ii) to extension that "may affect the whole lithosphere in a region of intracontinental convergence, if surface elevation has been increased by the removal of a lithospheric root". In this second case Platt (1993) notes that "extension may be accompanied by magmatism and an evolution towards higher temperature during decompression of the metamorphic terrain". We note that the same applies to a terrane-stack affected by lithospherescale extension, as proposed in this paper, and we therefore conclude that the role of lithosphere-scale extension needs be reconsidered.

In many respects the type of data needed to resolve this debate will come from the combination of structural geology, metamorphic petrology, and microstructure-focussed geochronology. There are now several examples of high-pressure and ultra-high-pressure terranes that involve a thinly sliced tectonometamorphic stratigraphy (e.g. Avigad, 1992), and the elucidation of the detail of the pressure-temperaturetime evolution of these individual slices should provide the critical information that would allow firm conclusions to be reached. It is already evident that more complex $\mathrm{P}-\mathrm{T}$ paths will be necessary if we are to explain the observed relations between metamorphism, fabric, and microstructure in such zones (Wakabayashi, 2004; Forster and Lister, 2005; Beltrando et al., 2007). It is necessary also to incorporate the detail evident in studies focussed on the emplacement of Franciscan as well as Tethyan ophiolites (Wakabayashi and Dilek, 2000; Dilek, 2003; Wakabayashi and Dilek, 2003).

\section{Orogen-scale tectonic shuffle zones}

The simple model advocated by England and Thompson (1984) did much to influence modern tectonic theory, but took no real cognizance of the effects of deformation and/or movement on major structures during orogeny. Therefore we set out to provide a slightly more realistic alternative, which we illustrate in Fig. 12. This is a simple model of domino-like shuffling in terrane-stacks. No scale is given, for such a model is applicable over a range of scales from that of a lithospheric terrane-stacks to that of a typical tectonic shuffle zone encountered in a field investigation.

The most potent predictions of the simple models illustrated in Fig. 12 are their quite specific predictions as to geometry. A mode I inversion cycle (as illustrated in Fig. 12a-e) starts with the stacking of individual tectonic slices (or geological terranes) during progressive shortening, leading to vastly over thickened continental crust. The nappe pile may subsequently be extended with the locus of extensional movement either parallel to or at a small angle to the existing terrane boundaries. In this case existing faults and/or shear zones may be reactivated, but because they do not move exactly in the same plane, lenses of relatively high pressure rock may be stranded below extensional detachments, attesting to a cycle of "push-pull' tectonics (Fig. 2). The pre-existing nappe pile and associated stratigraphic columns can become highly attenuated by extensional shear zones and detachment faults during this process. 
If we follow the application of this simple model into a second "push-pull" cycle, several circumstances might apply. In the simplest case mode I inversion cycles may be repeated several times, as terranes in the previously extended continental crust again thrust over each other, slicing and re-slicing the orogen (Fig. 12a-e), while shifts in the locus of relative movement will produce a predictable tectonometamorphicstratigraphy with each slice having a distinct tectonothermal evolution. A more complex geometry might see inversion crumple previously extended continental crust into upright folds, including upright folds developed on a crustal-scale. Subsequently, steeply dipping normal faults or extensional shear zones might transect these structures (e.g. as in New Caledonia, Rawling and Lister, 1999), producing complexity that we have not attempted to illustrate.

A second scenario supposes that renewed shortening results in a vergence change applied to the extended nappe pile, with the result that crustal-scale cascades of recumbent folds may form. Each tectonic slice is bounded by a recumbently folded extensional contact, defined by a detachment fault or a ductile shear zone (Fig. 12f). Subsequent extensional tectonism develops low-angle detachment faults and/or ductile shear zones that transect these cascades (Fig. 12g). Nappelike recumbent folds with highly attenuated lower-limbs result, but the kinematics during the earlier period of recumbent folding are not at all related to the kinematics that apply during the subsequent period of extensional tectonism. As noted by Forster and Lister (2008) this provides an explanation for an enigmatic geometry observed repeatedly in the Western Alps (e.g. in the Vanoise Massif). Earlier detachments and/or extensional shear zones are first recumbently folded, in crustal-scale cascades, and then transected by a second set of extensional shear zones. Structural geology has automatically assumed a relation between recumbent folds and underlying or overlying ductile shear zones, and developed a model of progressive evolution (i.e. in the fold nappe model as applied throughout the European Alps). This assumption appears to have been erroneous. Most structures assumed to be fold nappes within the European Alps now appear to be trains of recumbent folds transected by (unrelated) extensional ductile shear zones (cf Fig. 12f).

\section{Discussion}

The role of tectonic mode switches in determining the nature of orogenesis has engaged our research now for many years. The subject is not static, however, and discoveries continue apace. Important advances have been made using modeling and simulation studies (e.g. Jamieson et al., 1996; Beaumont et al., 2001; Burov et al., 2001; Gerya et al., 2002; Gerya and Stöckhert, 2002; Beaumont et al., 2004; Burg and Gerya, 2005; Gerya and Stöckhert, 2005; Beaumont et al., 2006; Warren et al., 2008). The difficulty is that these applications of computer models have been limited by an inability to properly deal with discontinuities in continuous media, and by the limitations of the assumptions made as to kinematic boundary constraints in any particular model. For example the semi-independent mobility of the subduction hinge during roll-back and the ability of the orogenic interface to flow over or to be pushed over the subduction hinge of a rolling-back subduction zone are presently issues that are not taken into account. The other issue that has been difficult to take into account is the rheology of real rocks, since this rheology involves complex interactions between dynamic hardening and/or softening, and the competition between the storage of elastic potential energy and its dissipation as the result of a number of thermally activated processes. Deformation mechanisms also involve mass transfer processes. Thus, whereas modeling and simulation do allow the formulation of particular hypotheses and the testing of their physical viability, there are deficiencies to be overcome before such studies can take their rightful place in terms of providing a virtual laboratory enabling geologists to accurately predict the outcome of specific geodynamic scenarios.

A second aspect that deserves comment in this discussion is the routine assumption that the pressure-temperature-time evolution followed by a particular rock mass can be exactly constrained by the locus of thermobarometric estimates as to the growth conditions for successions of mineral assemblages. Our understanding of the thermomechanical evolution of orogens increased dramatically as the result of papers written by England (1978), England and Thompson (1984) and Thompson and England (1984). The elegance of these models ensured that to this day metamorphic petrologists adhere strictly to the notion that rocks in orogens follow a simple pressuretemperature loop. But there are now many (contentious) issues that challenge the England-Thomson model in quite a fundamental way. For example the timescales involved in Barrovian metamorphism (Oliver et al., 2000; Faryad and Chakraborty, 2005; Johnson and Strachan, 2006) potentially eliminate models that rely on radioactive heating as the mechanism of heat input (e.g., models as proposed by Jamieson et al., 1996, 1998; Beaumont et al., 2001, 2004, 2006). Modeling and simulation studies need focus on mechanisms of heat input that are consistent with the short time scales now reported. This means that attention is now being paid to: a) advective transport by fluids and/or magma (Ague and Baxter, 2007; Viete et al., 2007; cf Jamieson et al., 1998); or b) the generation of heat as the result of mechanical work during deformation (e.g. England et al., 1992; Burg and Gerya, 2005).

The England and Thompson (1984) model uncritically assumed instantaneous deformation of an orogen, and predicted its subsequent thermal evolution solely on the basis of radioactive heating and erosional exhumation. Should terrane-stacking models apply there would be, of necessity, great changes introduced into the concepts that follow from dedicated application of the England-Thompson model. For example the P-T-t envelope defined by the locus of successive estimates of metamorphic conditions would define nothing more than a succession of transiently attained P-T conditions, with each shuffle of the terrane-stack leading to an additional assemblage in the sequence. Beltrando et al. (2007) provide a first indication that this can be the case, demonstrating pressure pulses and a geodynamic scenario consistent only with the terrane-stacking model. The time-scales involved in the terrane-stacking model are also far shorter than needed by radioactive heating models, since variation in pressure can be quite rapid, and temperature is influenced by advection of heat in fluids and magma introduced during active tectonism. This is consistent with the several lines of evidence that demonstrate time-scales for metamorphism orders of magnitude shorter than that required by the EnglandThompson model (e.g., Camacho et al., 2005; Ague and Baxter, 2007; Viete et al., 2007)

We emphasize that not everything discussed in these pages has been totally resolved and understood. For example one of the strangest aspects of this evolving story is that (in the language of tectonic sequence diagrams, Forster and Lister, 2008) tectonic mode switches involving "push-pull" inversion cycles are typified by $F_{R} \Delta S Z$ cycles. A period of recumbent folding $\left[\mathrm{F}_{\mathrm{R}}\right]$ may not always signify crustal shortening, but occasionally it can be demonstrated to be the case (e.g. Rawling and Lister, 1999, 2002). High-pressure metamorphic mineral growth at or about the time of the tectonic mode switch seems to be particularly common, in particular marked by periods of (very short-lived) static growth $[\Delta]$ of porphyroblasts (Forster and Lister, 2005). These minerals commence growth immediately prior to the time that the rock mass is cut by extensional ductile shear zones [SZ], and growth of some porphyroblasts typically continues into the period of shear zone operation. It is also not immediately evident why the timing of these short-lived metamorphic mineral growth events should be synchronized over such very large distances.

We also emphasize that there are many examples of phenomena as discussed in this paper other than those described: most of these 
examples are untapped in terms of their potential to further elucidate the role of tectonic mode switches in affecting the nature of orogenesis. For example the modern Andean chain exhibits the effects of a "pull-push" mode switch. Jordan et al. (2001) show that $>3000 \mathrm{~km}$ of the strike length of the Andean chain was thrown into lithospheric extension from $\sim 28 \mathrm{Ma}$, with extension apparently increasing in intensity southwards. Using concepts developed in this paper this can be explained by accelerated westward roll-back of the hinge of the adjacent subduction zone. If this is correct then roll-back appears to have accelerated during a period of rapid convergence, coincidentally shortly after the time that eastward roll-back of the Scotia Arc began to generate ocean crust (Cunningham et al., 1995). At 20-18 Ma, a switch to horizontal compression took place leading to widespread basin inversion marking the beginning of construction of the modern Andes.

There are also many issues of scale and process to unravel, and as well, debates need to take place that are in essence related to terminology. Some of these are related to a lack of understanding of the large-scale movement picture, for example, there are many cases where extension takes place synchronously with thrusting and net convergence. In the Alps "foreland basin migration in the external zones was synchronous with extensional shearing unroofing the eclogite" (Wheeler et al., 2001). It can be argued that therefore these orogens display examples of simultaneous extension and shortening, but this inference is correct only in part. Geometry requires that there must always be a basal thrust that marks the edge of the convergent boundary. To some extent, even if the volume of rock considered is merely that part of the orogen immediately adjacent to the frontal tip of the thrust, there must be rock that is subject to horizontal shortening at the same time as other rocks are being subject to horizontal extension.

It is not correct to assert that any thrust is by definition overlain by a mass of rock being subject to horizontal shortening. Lister et al. (2001) illustrate the geometry to be expected during a surge of collapsing orogenic crust, with the entire over-riding plate subject to horizontal extension for the entire time that it thrusts over the foreland. Forster and Lister (2005) illustrate how several episodes of metamorphism can result in this way. A surge can take place each time a new frontal thrust breaks, since this provides a weak basal fault allowing collapse of thrust sheets stacked up during a preceding period of crustal and/or lithospheric shortening. Forster and Lister (2005) show that this domino-like stacking followed by domino-like collapse leads to tectonic shuffle zones, and a thinly-sliced tectonometamorphic stratigraphy. Each tectonic mode switch is marked by the breaking of a new thrust, a surge of the orogen over the foreland, and the conversion of previously operating thrusts into lowangle detachment faults. Convergence takes place throughout, independent of whether or not the overlying orogen is extending or shortening.

\section{Conclusion}

Plate tectonic theory evolved based on the notion of rigid plates. Theories as to the nature of orogenesis thus lacked a critical datum, and many doubted that the internal motions within orogens could ever be related to the plate tectonic framework. Perhaps as a result current theories as to the nature of orogenesis have not taken the implications of semi-independent motion of the orogenic interface into consideration. Field evidence that potentially manifests the consequences of such orogen-scale events is often relegated to the category of a phenomenon of only local significance, and therefore not important to the elucidation of the tectonic evolution of the orogen as a whole.

The convergence of two points (one on each plate, with each point distal to the orogenic zone) does not determine the tectonic mode in the intervening orogen. This behaviour is determined by the dynamics of interaction across the orogenic zone, with four main modes of operation. Using simple terms to describe the interaction with the hinge of the adjacent subducting plate, and using this marker as a datum, these mechanisms can be described as: a) "push against"; b) "push over"; "pull away from"; or d) "collapse over". A change from one tectonic mode to another will result in large areas of the orogen being subject to a switch from wholesale horizontal shortening to horizontal extension, or vice versa. Tectonic mode switches can take place even during steady overall convergence (e.g., during the early stages of the India-Asia collision). Where the behaviour of an adjacent slab determines the outcome, the tectonic mode within the orogen will be determined by processes taking place at or near the interface, as well as in response to changes in the global pattern of relative plate motions.

Tectonic mode switches are readily induced by accretion events. The arrival of a continental ribbon, oceanic plateau or island arc at the intervening subduction zone will change the relative motion of the subduction hinge in respect to the over-riding plate, with the result that either "push-back" or "hinge-advance" will take place. The orogen will then undergo a period of lithosphere-scale shortening. This period of shortening can be terminated by the act of accretion since this transfer once again allows "hinge-retreat", "roll-back" or "pullback" to take place. The orogen can thus be abruptly switched from lithosphere-scale horizontal shortening to lithosphere-scale horizontal extension. Several such tectonic mode switches can take place during a period of overall steady convergence of the same tectonic plates.

The concepts we advocate provide a logical framework allowing explanation for the differences between many modern and ancient orogens, e.g., why some orogens are typified by high-pressure metamorphism while others are a showcase for regional high temperature low-pressure and/or high temperature metamorphism and anatexis. These concepts also allow resolution of many of the issues that surround the existence of thinly sliced and/or recumbently folded tectonometamorphic stratigraphy, in particular why most (if not all) exposures of high-pressure and ultra-high-pressure metamorphic rocks occur in or near such orogen-scale tectonic shuffle zones.

The sequencing of tectonic mode switches determines the thermal evolution of an orogen, in particular if significant strains accumulate before a mode switch takes place. Orogens subjected to abrupt "pullpush" sequences are characterized by intervening episodes of hightemperature metamorphism, whereas orogens subjected to "pushpull" sequences exhibit intervening episodes of high-pressure metamorphism. In particular we note that many segments within the modern Alpine-Himalayan chain are typified by repeated "pushpull" cycles. The accretion of a continental ribbon, an island arc, or an oceanic plateau, is preceded by a period during which terranestacking and obduction of oceanic basins in the over-riding plate sends crustal rocks deep into the lithosphere. Terrane-stacking itself then leads to high-pressure metamorphism.

Accretion can take place either as the result of the operation of a giant megathrust, or as the result of a new subduction zone being initiated. The act of accretion leads to an initial period of rapid slab rollback. Slab roll-back leads to extension in the adjacent orogen, distending the over-riding terrane-stack, and rapidly exhuming thin tectonic slivers that have previously been metamorphosed at deep levels in the lithosphere. The tectonic shuffle zones that form in consequence allow explanation of enigmatic disrupted tectonothermal stratigraphic stacks that are found in classic localities in many mountain belts.

\section{Acknowledgments}

M.A. Forster acknowledges the support of an Australian PostDoctoral Fellowship and currently an Australian Research Fellowship 
provided by the Australian Research Council (ARC). Research support was provided by ARC Discovery Grants DP0449975 "Revisiting The Alpine Paradigm: The Role Of Inversion Cycles In The Evolution Of The European Alps”, DP0343646 “Tectonic Reconstruction of the Evolution of the Alpine-Himalayan Orogenic Chain", and DP0877274 "Tectonic mode switches and the nature of orogenesis". The paper greatly benefited from reviews provided by John Wakabayashi and George Davis (and now includes specific sentences provided by these reviewers). The encouragement of numerous colleagues including Peter Betts and Peter Cawood is gratefully acknowledged.

\section{References}

Aitchison, J.C., Ireland, T.R., Clarke, G.L., Cluzel, D., Davis, A.M., Meffré, S., 1998. Regiona implications of $\mathrm{U} / \mathrm{Pb}$ SHRIMP age constraints on the tectonic evolution of New Caledonia. Tectonophysics 299, 333-343. doi:10.1016/S0040-1951(98)00211-x.

Ague, J.J., Baxter, E.F., 2007. Brief thermal pulses during mountain building recorded by Sr diffusion in apatite and multicomponent diffusion in garnet. Earth and Planetary Science Letters 261, 500-516. doi:10.1016/j.epsl.2007.07.017.

Avigad, D., 1992. On the exhumation of coesite-bearing rocks in the Dora-Maira massif (Western Alps, Italy). Geology 20. doi:10.1130/0091-7613 (1992)020<0947: EOCBRI $>2.3 . C O ; 2$.

Baldwin, S.L., Rawling, T., Fitzgerald, P.G., 2007. Thermochronology of the New Caledonian high-pressure terrane: implications for middle Tertiary plate boundary processes in the southwest Pacific. Convergent Margin Terranes and Associated Regions: A Tribute to W.G. Ernst. Geol. Soc. Amer. Special Paper, vol. 419, pp. 117-134. doi:10.1130 2006.2419(06).

Beaumont, C., Jamieson, R.A., Nguyen, M.H., Lee, B., 2001. Himalayan tectonics explained by extrusion of a low-viscosity channel coupled to focused surface denudation. Nature 414, 738-742. doi:10.1038/414738a.

Beaumont, C., Jamieson, R.A., Nguyen, M.H., Medvedev, S., 2004. Crustal channel flows: 1. Numerical models with applications to the tectonics of the Himalayan-Tibetan orogen. Journal of Geophysics Research 109, B06406. doi:10.1029/2003JB002809.

Beaumont, C., Nguyen, M., Jamieson, R.A., Ellis, S., 2006. Crustal flow modes in large hot orogens. In: Law, R.D., Searle, M.P., Godin, L. (Eds.), Channel Flows, Ductile Extrusion and Exhumation in Continental Collision Zones. Geological Society London Specia Publications, vol. 268, pp. 91-145, doi:10.1144/GSL.SP.2006.268.01.05. London.

Beltrando, M., Lister, G., Hermann, J., Forster, M., Compagnoni, R., 2007. Deformation mode switches in the Penninic units of the Urtier Valley (Western Alps): evidence for a dynamic orogen. Earth and Planetary Science Letters 256, 372-388. doi:10.1016/j.jsg.2007.10.008.

Bendick, R., Bilham, R., 2001. How perfect is the Himalayan arc? Geology 29, 791-794. doi:10.1130/0091-7613 (2001)029<0791:HPITHA>2.0.CO;2.

Betts, P.G., Giles, D., 2006. The 1800-1100 Ma tectonic evolution of Australia. Precambrian Research 144, 92-125. doi:10.1016/j.precamres.2005.11.006.

Betts, P.G., Giles, D., Lister, G.S., Frick, L.R., 2002. Evolution of the Australian lithosphere Australian Journal of Earth Sciences 49, 661-696. doi:10.1046/j.1440-0952.2002.00948.x.

Betts, P.G., Giles, D., Mark, G., Lister, G.S., Goleby, B.R., Aillères, L., 2006. Synthesis of the Proterozoic evolution of the Mt Isa Inlier. Australian Journal of Earth Sciences 53, 187-211. doi:10.1080/08120090500434625.

Boutelier, D., Chemenda, A., Jorand, C., 2004. Continental subduction and exhumation of high-pressure rocks; insights from thermo-mechanical laboratory modelling. Earth and Planetary Science Letters 222, 209-216. doi:10.1016/j.epsl.2004.02.013.

Brun, J.-P., Faccenna, C., 2008. Exhumation of high-pressure rocks driven by slab rollback. Earth and Planetary Science Letters 272,1-7. doi:10.1016/j.epsl.2008.02.038.

Burchfiel, B.C., Royden, L.H., 1985. North-south extension within the convergent Himalayan region. Geology 13, 679-682. doi:10.1130/0091-7613 (1985)13<679: NEWTCH>2.0.CO;2.

Burchfiel, B.C., Chen, Z., Hodges, K.V., Liu, Y., Royden, L.H., Deng, C., Xu, J., 1992. The south Tibetan detachment system, Himalayan orogen: extension contemporaneous with and parallel to shortening in a collisional mountain belt. Special Papers in Geological Society of America 26941 pp.

Burg, J., Gerya, T.V., 2005. The role of viscous heating in Barrovian metamorphism of collisional orogens: thermomechanical models and application to the Lepontine Dome in the Central Alps. Journal of Metamorphic Geology 23, 75-95. doi:10.1111/j.15251314 2005.00563.x.

Burov, E., Jolivet, L., Le Pourhiet, L., Poliakov, A., 2001. A thermomechanical model of exhumation of high pressure (HP) and ultra-high pressure (UHP) metamorphic rocks in Alpine-type collision belts. Tectonophysics 342, 113-136. doi:10.1016 S0040-1951(01)00158-5.

Camacho, A., Lee, J.K.W., Hensen, B.J., Braun, J., 2005. Short-lived orogenic cycles and the eclogitization of cold crust by spasmodic hot fluids. Nature 435, 1191-1196. doi:10.1038/nature03643.

Chemenda, A.I., Mattauer, M., Malavieille, J., Bokun, A.N., 1995. A mechanism for syncollisional rock exhumation and associated normal faulting: results from physical modelling. Earth Planetary Science Letters 132, 225-232. doi:10.1016/0012-821X (95)00042-B.

Chemenda, A.I., Burg, J.-P., Mattauer, M., 2000. Evolutionary model of the Himalaya-Tibet system: geopoem based on new modelling, geological and geophysical data. Earth and Planetary Science Letters 174, 397-409. doi:10.1016/S0012-821X(99)00277-0.

Chemenda, A.I., Hurpin, D., Tang, J.C., Stephan, J.F., Buffet, G., 2001. Impact of arccontinent collision on the conditions of burial and exhumation of UHP/LT rocks; experimental and numerical modelling; exhumation of high pressure rocks; kinetic, thermal and mechanical constraints. Tectonophysics 342, 137-161. doi:10.1016/S0040-1951(01)00160-3.

Cloos, M.,1982. Flow melanges: numerical modelling and geologic constraints on their origin in the Franciscan subduction complex, California. Bulletin of the Geological Society of America 93, 330-345. doi:10.1130/0016-7606 (1982)93<330:FMNMAG > 2.0.CO;2

Cloos, M., Carlson, W.D., Gilbert, M.C., Liou, J.G., Sorensen, S.S., 2007. Convergent Margin Terranes and Associated Regions: A Tribute to W.G. Ernst. Geological Society of America. Special Paper 419, ISBN 0813724198, 9780813724195, 273 pp.

Collins, W.J., 2002. Hot orogens, tectonic switching, and creation of continental crust. Geology 30, 535-538. doi:10.1130/0091-7613 (2002)030<0535:HOTSAC >2.0.CO;2.

Coney, P.J., Reynolds, S.J., 1977. Cordilleran Benioff zones. Nature 270, 403-406. doi:10.1038/270403a0.

Coney, P.J., Harms, T.A., 1984. Cordilleran metamorphic core complexes: Cenozic extensional relics of Mesozoic compression. Geology 12, 550-554. doi:10.1130/ 0091-7613 (1984)12<550:CMCCCE $>2.0$. CO;2

Cunningham, W.D., Dalziel, I.W.D., Lee, T.Y., Lawver, L.A., 1995. Southernmost South America-Antarctic Peninsula relative plate motions since $84 \mathrm{Ma}$ : implications for the tectonic evolution of the Scotia Arc region. Journal of Geophysical Research 100 (B5), 8257-8266. doi:10.1029/95JB00033.

Davis, D., Suppe, J., Dahlen, F.A., 1983. Mechanics of fold-and-thrust belts and accretionary wedges. Journal of Geophysical Research 88,1153-1172. doi:10.1029/JB088iB02p01153.

de Sigoyer, J., Guillot, S., Dick, P., 2004. Exhumation of the ultrahighpressure Tso Morari unit in eastern Ladakh NW Himalaya: a case study. Tectonics 23. doi:10.1029/2002TC001492.

Dewey, J.F., 1988. Extensional collapse of orogens. Tectonics 7, 1123-1139. doi:10.1029/ TC007i006p01123.

Dilek, Y., 2003. Ophiolite Concept and its Evolution. In: Ophiolite Concept and the Evolution of Geological Thought. Geological Society of America. doi:10.1130/0-8137-2373-6.1. Special Paper 373,1-16.

Drummond, B.J., Goleby, B.R., Goncharov, A.G., Wyborn, L.A.I., Collins, C.D.N., MacCready, T., 1998. Crustal-scale structures in the Proterozoic Mount Isa inlier of north Australia: their seismic response and influence on mineralisation. Tectonophysics 288, 43-56. doi:10.1016/S0040-1951(97)00282-5.

Eaton, G.P., 1984. The Miocene Great Basin of western North America as an extending back-arc region. Tectonophysics 102, 275-295. doi:10.1016/0040-1951(84)90017-9.

England, P.C., 1978. Some thermal considerations of the Alpine metamorphism: past present and future. Tectonophysics 2, 21-40. doi:10.1016/0040-1951(78)90103-8.

England, P.C., Thompson, A.B., 1984. Pressure-temperature-time paths of regional metamorphism I. Heat transfer during the evolution of regions of thickened continental crust. Journal of Petrology 25, 894-928.

England, P., Molnar, P., 2005. Late Quaternary to decadal velocity fields in Asia. Journal of Geophysical Research 110, B12401. doi:10.1029/2004jb003541.

England, P., Le Fort, P., Molnar, P., Pêcher, A., 1992. Heat sources for Tertiary metamorphism and anatexis in the Annapurna-Manaslu region Central Nepal. Journal of Geophysical Research 97, 2107-2128. doi:10.1029/91JB02272.

Ernst, W.G., 2001. Subduction, ultrahigh-pressure metamorphism, and regurgitation of buoyant crustal slices - implications for arcs and continental growth. Physical of Earth Planetary Interior 127, 253-275. doi:10.1016/S0031-9201(01)00231-x.

Faryad, S.W., Chakraborty, S., 2005. Duration of Eo-Alpine metamorphic events obtained from multicomponent diffusion modeling of garnet: a case study from the eastern Alps. Contributions to Mineralogy and Petrology 150, 306-318. doi:10.1007/s00410005-0020-0.

Forster, M.A., Lister, G.S., 2003. Cretaceous metamorphic core complexes in the Otago Schist, New Zealand. Australian Journal of Earth Sciences 50, 181-198. doi:10.1046/ j.1440-0952.2003.00986.x.

Forster, M.A., Lister, G.S., 2005. Several distinct tectonometamorphic slices in the Cycladic eclogite-blueschist belt, Greece. Contributions to Mineralogy and Petrology 150, 523-545. doi:10.1007/s00410-005-0032-9.

Forster, M.A., Lister, G.S., 2008. Tectonic sequence diagrams and the structural evolution of schist and gneisses in multiply deformed terranes. Journal of the Geological Society, London 165, 923-939.

Ganne, J., Marquer, D., Rosenbaum, G., Bertrand, J.-M., Fudral, S., 2006. Partitioning of deformation within a subduction channel during exhumation of high-pressure rocks: a case study from the Western Alps. Journal of Structural Geology 28, 1193-1207. doi:10.1016/j.jsg.2006.02.011.

Gerya, T.V., Stoeckhert, B., 2002. Exhumation rates of high pressure metamorphic rocks in subduction channels; the effect of rheology. Geophysical Research Letters 29, 4. doi:10.1029/2001GL014307.

Gerya, T., Stöckhert, B., 2005. Two-dimensional numerical modelling of tectonic and metamorphic histories at active convergent margins. Internation Journal of Earth Science. doi:10.1007/s00531-005-0035-9.

Gerya, T.V., Stoeckhert, B., Perchuk, A.L., 2002. Exhumation of high-pressure metamorphic rocks in a subduction channel; a numerical simulation. Tectonics 21, 19. doi:10.1029/2002TC001406.

Gutscher, M.A., Spakman, W., Bijwaard, H., Engdahl, E.R., 2000. Geodynamics of flat subduction: seismicity and tomographic constraints from the Andean margin. Tectonics 19, 814-833. doi:10.1029/1999TC001152.

Jade, S., Bhatt, B.C., Yang, Z., Bendick, R., Gaur, V.K., Molnar, P., Anand, M.B., Kumar, D., 2004. GPS measurements from the Ladakh Himalaya, India: preliminary tests of plate-like or continuous deformation in Tibet. Geological Society of America Bulletin 116, 1385-1391. doi:10.1130/B25357.1.

Jamieson, R.A., Beaumont, C., Hamilton, J., Fullsack, P., 1996. Tectonic assembly of inverted metamorphic sequences. Geology 24, 839-842. doi:10.1130/0091-7613 (1996)024<0839:TAOIMS>2.3.CO;2.

Jamieson, R.A., Beaumont, C., Fullsack, P., Lee, B., 1998. Barrovian regional metamorphism: where's the heat? In: Treloar, P.J., O'Brien, P. (Eds.), What Drives Metamorphism and Metamorphic Reactions. Geol. Soc. Spec. Publ., vol. 138, pp. 23-45. 
Jayko, A.S., Blake, M.C., Harms, T., 1987. Attenuation of the Coast Range Ophiolite by extensional faulting, and nature of the Coast Range 'Thrust', California. Tectonics 6, 475-488. doi:10.1029/TC006i004p00475.

Johnson, M.R.W., Strachan, R.A., 2006. A discussion of possible heat sources during nappe stacking: the origin of Barrovian metamorphism within the Caledonian thrust sheets of NW Scotland. Journal of the Geological Society 163, 579-582. doi:10.1144/0016-764920-168.

Jolivet, L., Daniel, J.M., Truffert, C., Goffé, B., 1994. Exhumation of deep crustal metamorphic rocks and crustal extension in arc and back-arc regions. Lithos 33, 3-30. doi:10.1016/0024-4937(94)90051-5.

Jolivet, L., Faccenna, C., Goffé, B., Burov, E., Agard, P., 2003. Subduction tectonics and exhumation of high-pressure metamorphic rocks in the Mediterranean orogens. American Journal of Science 303, 353-409. doi:10.2475/ajs.303.5.353.

Jordan, T.E., Isacks, B.L., Allmendinger, R.W., Brewer, J.A., Ramos, V.A., Ando, C.J., 1983. Andean tectonics related to geometry of subducted Nazca Plate. Geological Society of America Bulletin 94, 341-361. doi:10.1130/0016-7606 (1983)94<341:ATRTGO>2.0. $\mathrm{CO} ; 2$.

Jordan, T.E., Burns, W.M., Veiga, R., Pángaro, F., Copeland, P., Kelley, S., Mpodozis, C., 2001. Extension and basin formation in the southern Andes caused by increased convergence rate: a mid-Cenozoic trigger for the Andes. Tectonics 20, 308-324. doi:10.1029/1999TC001181.

Karig, D.E., 1980. Material transport within accretionary prisms and the 'knocker' problem. Journal of Geology 88, 27-39.

Kay, S.M., Abbruzzi, J.M., 1996. Magmatic evidence for Neogene lithospheric evolution of the central Andean "flat-slab" between $30^{\circ} \mathrm{S}$ and $32^{\circ} \mathrm{S}$. Tectonophysics $259,15-28$. doi:10.1016/0040-1951(96)00032-7.

Lister, G.S., Etheridge, M.A., 1989. Towards a general model: detachment models for uplift and volcanism in the eastern highlands, and their application to the origin of passive margin mountains. In: Johnson, R.W., Knutson, J., Taylor, S.R. (Eds.), Intraplate volcanism in eastern Australia and New Zealand, pp. 297-313.

Lister, G.S., Betts, P.G., Giles, D., MacCready, T., 1997. The active tectonic environment of ore deposition in the Mount Isa terrane. In: Aillères, L., Betts, P. (Eds.), Structural Elements of the Eastern Successions - A Field Guide Illustrating the Structural Geology of the Eastern Mount Isa Terrane, Australia, vol. 63. Australian Crustal Research Centre Publication. 175p.

Lister, G.S., Forster, M.A., Rawling, T.J., 2001. Episodicity during orogenesis, vol. 184 Geological Society of London, pp. 89-113. doi:10.1144/GSL.SP.2001.184.01.06. Special Publication.

Lister, G., Kennett, B., Richards, S., Forster, M., 2008. Boudinage of a stretching slablet implicated in earthquakes beneath the Hindu Kush. Nature Geoscience 1, 196-201. doi:10.1038/ngeo132.

Lonergan, L., White, N., 1997. Origin of the Betic-Rif mountain belt. Tectonics 16, 504-522. doi:10.1029/96TC03937.

MacCready, T., Goleby, B.R., Goncharov, A., Drummond, B.J., Lister, G.S., 2006. Shifts in the locus of crustal thickening during Mesoproterozoic orogenesis in the Mt Isa Terrane. Australian Journal of Earth Sciences 53, 41-53. doi:10.1080/08120090500432405.

Mantovani, E., Viti, M., Babbucci, D., Tamburelli, C., Albarello, D., 2001. Back arc extension: which driving mechanism? In: Jessell, M. J. 2001. General Contributions: 2001. Journal of the Virtual Explorer 3, 17-44.

Michel, G.W., Becker, M., Angermann, D., Reigber, C., Reinhart, E., 2000. Crustal motion in E- and SE-Asia from GPS measurements. Earth Planets Space 52, 713-720.

Miller, M., Smith, W.H.F., Kuhn, J., Sandwell, D.T., An Interactive Global Map of Sea Floor Topography Based on Satellite Altimetry and Ship Depth Soundings. NOAA Laboratory for Satellite Altimetry. < http://ibis.grdl.noaa.gov/cgi-bin/bathy/bathD.pl $>$.

Nichols, S., 2001. Broken Hill Model - bringing portability to 3D geoscience. In: Aillères, L., Rawling, T. (Eds.), Animations in Geology. Journal of the Virtual Explorer, vol. 4, p. 07. doi:10.3809/jvirtex.2001.0002.

Oliver, G.J.H., Chen, F., Buchwaldt, R., Hegner, E., 2000. Fast tectonometamorphism and exhumation in the type area of the Barrovian and Buchan zones. Geology 28, 459-462. doi:10.1130/0091-7613 (2000)028<0459:FTAEIT>2.3.CO;2.

Platt, J.P., 1986. Dynamics of orogenic wedges and the uplift of high pressure/ metamorphic rocks. Geological Society of America Bulletin 97, 1037-1053. doi:10.1130/0016-7606 (1986)97<1037:DOOWAT>2.0.CO;2.

Platt, J.P., 1993. Exhumation of high-pressure rocks: a review of concepts and processes. Terra Nova 5, 119-133. doi:10.1111/j.1365-3121 1993.tb00237.x.

Platt, J.P., Vissers, R.L.M., 1989. Extensional collapse of thickened continental lithosphere: a working hypothesis for the Alboran Sea and the Gibraltar arc. Geology 17, 540-543. doi:10.1130/0091-7613 (1989)017<0540:ECOTCL $>2.3 . C 0 ; 2$.

Ramos, V.A., Cristallini, E.O., Pérez, D.J., 2002. The Pampean flat-slab of the Central Andes. Journal of South American Earth Sciences 15, 59-78. doi:10.1016/S08959811(02)00006-8.

Rawling, T.J., 1998. Oscillating orogenesis and exhumation of high-pressure rocks in New Caledonia, SW Pacific. Ph.D. thesis, Monash University.

Rawling, T.J., Lister, G.S., 1999. Oscillating modes of orogeny in the Southwest Pacific and the tectonic evolution of New Caledonia. In: Ring, U., Brandon, M.T., Lister, G.S. Willett, S.D. (Eds.), Exhumation Processes: Normal Faulting, Ductile Flow and Erosion, vol. 154. Geological Society, London, pp. 109-128. doi:10.1144/GSL. SP.1999.154.01.05. Special Publication.

Rawling, T.J., Lister, G.S., 2002. Large-scale structure of the eclogite-blueschist belt of New Caledonia. Journal of Structural Geology 24, 1239-1258. doi:10.1016/S01918141(01)00128-6.

Ring, U., Layer, P.W., 2003. High-pressure metamorphism in the Aegean, eastern Mediterranean: underplating and exhumation from the Late Cretaceous until
Miocene to Recent above the retreating Hellenic subduction zone. Tectonics 22, 1022. doi:10.1029/2001TC001350.

Rosenbaum, G., Lister, G.S., Duboz, C., 2002. Reconstruction of the tectonic evolution of the western Mediterranean since the Oligocene. Journal of the Virtual Explorer 8, 107-130. doi:10.3809/jvirtex.2002.0039.

Royden, L.H., 1993. Evolution of retreating subduction boundaries formed during continental collision. Tectonics 12, 629-638. doi:10.1029/92TC02641.

Royden, L., Burchfiel, B.C., 1987. Thin-skinned extension within the convergent Himalayan region: gravitational collapse of a Miocene topographic front, vol. 28. Geological Society, London, pp. 611-619. doi:10.1144/GSL.SP.1987.028.01.40. Special Publications

Royden, L.H., Husson, L., 2006. Trench motion, slab geometry and viscous stresses in subduction systems. Geophysical Journal International 167, 881-905. doi:10.1111/ j.1365-246X.2006.03079.x.

Sandiford, M., 1989. Horizontal structures in granulite terrains: a record of mountain building or mountain collapse? Geology 17, 449-452. doi:10.1130/0091-7613 (1989)017<0449:HSIGTA>2.3.CO;2.

Schellart, W.P., 2004a. Kinematics of subduction and subduction-induced flow in the upper mantle. Journal of Geophysical Research 109, B07401. doi:10.1029/ 2004JB002970.

Schellart, W.P., 2004b. Quantifying the net slab pull force as a driving mechanism for plate tectonics. Geophysical Research Letters 31, L07611. doi:10.1029/2004GL019528.

Schellart, W.P., 2007. North-eastward subduction followed by slab detachment to explain ophiolite obduction and Early Miocene volcanism in Northland, New Zealand. Terra Nova 19, 211-218. doi:10.1111/j.1365-3121.2007.00736.x.

Schellart, W., Lister, G.S., 2004. Tectonic models for the formation of arc-shaped convergent zones and back-arc basins. In: Arlo, B.W., Sussman, A. (Eds.), Orogenic Curvature, vol. 383. Geological Society of America, pp. 237-258. Special Paper.

Schellart, W.P., Lister, G.S., Jessell, M.W., 2002. Analogue modelling of asymmetrical backarc extension. Journal of the Virtual Explorer 7,19-36. doi:10.3809/jvirtex.2002.0026.

Schellart, W.P., Lister, G.S., Toy, V.G., 2006. A Late Cretaceous and Cenozoic reconstruction of the Southwest Pacific region: tectonics controlled by subduction and slab rollback processes. Earth Science Reviews 76, 191-233. doi:10.1016/j.earscirev.2006.01.002.

Shervais, J.W., Kimbrough, D.L., Renne, P., Hanan, B.B., Murchey, B., Snow, C.A., 2004 Multi-stage origin of the Coast Range Ophiolite, California: implications for the life cycle of supra-subduction zone ophiolites. International Geology Review 46, 289-315. doi:10.2747/0020-6814.46.4.289.

Smith, W.H.F., Sandwell, D.T., 1997. Global sea floor topography from satellite altimetry and ship depth soundings. Science 277, 1956-1962. doi:10.1126/science.277.5334.1956.

Stegman, D.R., Freeman, J., Schellart, W.P., Moresi, L., May, D., 2006. Influence of trench width on subduction hinge retreat rates in 3-D models of slab rollback. Geochemistry Geophysics Geosystems 7, Q03012. doi:10.1029/2005GC001056.

Thompson, A.B., England, P.C., 1984. Pressure-Temperature-time paths of regional metamorphism II. Their inference and interpretation using mineral assemblages in metamorphic rocks. Journal of Petrology 25, 929-955.

Venn, C., 2001. The geodynamic evolution of the Mount Robe and Mount Franks region, Broken Hill, Australia: discovery of crustal-scale extensional shear zones and giant sheath folds. Unpublished Ph.D. thesis, Monash University, 280 pp.

Viete, D.R., Lister, G.S., Richards, S.W., Forster, M.A., Oliver, G.J.H., 2007. Time-scales and heat sources for metamorphism of the Barrovian series, Scotland.

Vigny, C., Socquet, A., Rangin, C., Chamot-Rooke, N., Pubellier, M., Bouin, M.-N., Bertrand, G. Becker, M., 2003. Present-day crustal deformation around Sagaing fault, Myanmar Journal of Geophysical Research 108 (B11), 2533. doi:10.1029/2002JB001999.

Wakabayashi, J., 2004. Tectonic mechanisms associated with P-T paths of regional metamorphism: alternatives to single-cycle thrusting and heating. Tectonophysics 392, 193-218. doi:10.1016/j.tecto.2004.04.012.

Wakabayashi, J., Dilek, Y., 2000. Spatial and temporal relationships between ophiolites and their metamorphic soles: a test of models of forearc ophiolite genesis. Geological Society of America, pp. 53-64. doi:10.1130/0-8137-2349-3.53. Special Paper 349.

Wakabayashi, J., Dilek, Y., 2003. What constitutes 'emplacement' of an ophiolite? Mechanisms and relationship to subduction initiation and formation of metamorphic soles. Geological Society London, pp. 427-447. doi:10.1144/GSL. SP.2003.218.01.22. Special Publications 218.

Warren, C.J., Beaumont, C., Jamieson, R.A., 2008. Modelling tectonic styles and ultrahigh pressure (UHP) rock exhumation during the transition from oceanic subduction to continental collision. Earth and Planetary Science Letters 267, 129-145. doi:10.1016/j.epsl.2007.11.025.

Wellman, H.W., 1966. Active wrench faults of Iran, Afghanistan and Pakistan. International Journal of Earth Sciences 55, 716-735. doi:10.1007/BF02029650.

Wernicke, B., 1985. Uniform-sense normal simple shear of the continental lithosphere Canadian Journal of Earth Science 22, 108-125. doi:10.1139/e85-009.

Wheeler, J., Reddy, S.M., Cliff, R.A., 2001. Kinematic linkage between internal zone extension and shortening in more external units in the NW Alps. Journal of the Geological Society, London 158, 439-443.

Whittaker, J.M., Müller, R.D., Sdrolias, M., Heine, C., 2007. Sunda-Java trench kinematics, slab window formation and overriding plate deformation since the Cretaceous Earth and Planetary Science Letters 255, 445-457. doi:10.1016/j.epsl.2006.12.031.

Wijbrans, J.R., Schliestedt, M., York, D., 1990. Single grain argon laser probe dating of phengites from the blueschist to greenschist transition on Sifnos (Cyclades, Greece). Contributions to Mineralogy and Petrology 104, 582-593. doi:10.1007/BF00306666.

Wortel, M.J.R., Spakman, W., 2000. Subduction and slab detachment in the Mediterranean-Carpathian Region. Science 290, 1910-1917. doi:10.1126/science.290.5498.1910. 